\title{
Different Species of $\alpha$-Synuclein Oligomers Induce Calcium Influx and Seeding
}

\author{
Karin M. Danzer, ${ }^{1}$ Dorothea Haasen, ${ }^{2}$ Anne R. Karow, ${ }^{1}$ Simon Moussaud, ${ }^{1}$ Matthias Habeck, ${ }^{3}$ Armin Giese,${ }^{3}$ \\ Hans Kretzschmar, ${ }^{3}$ Bastian Hengerer, ${ }^{1}$ and Marcus Kostka ${ }^{1}$ \\ ${ }^{1}$ Central Nervous System Research and ${ }^{2}$ Integrated Drug Discovery, Boehringer Ingelheim Pharma, 88397 Biberach, Germany, and ${ }^{3}$ Zentrum für \\ Neuropathologie und Prionforschung, Ludwig-Maximilians Universität München, 81377 München, Germany
}

\begin{abstract}
Aggregation of $\alpha$-synuclein ( $\alpha$-syn) has been linked to the pathogenesis of Parkinson's disease (PD) and other neurodegenerative diseases. Increasing evidence suggests that prefibrillar oligomers and protofibrils, rather than mature fibrils of $\alpha$-syn, are the pathogenic species in PD. Despite extensive effort on studying oligomerization of $\alpha$-syn, no studies have compared different oligomer species directly on a single-particle level and investigated their biological effects on cells. In this study, we applied a novel highly sensitive single molecule detection system that allowed a direct comparison of different oligomer types. Furthermore, we studied biological effects of different oligomer types on cells. For this purpose, we developed new oligomerization protocols, that enabled the use of these different oligomers in cell culture. We found that all of our three aggregation protocols resulted in heterogeneous populations of oligomers. Some types of oligomers induced cell death via disruption of cellular ion homeostasis by a presumably pore-forming mechanism. Other oligomer types could directly enter the cell resulting in increased $\alpha$-syn aggregation. Based on our results, we propose that under various physiological conditions, heterogeneous populations of oligomeric forms will coexist in an equilibrium. These different oligomer types lead directly or indirectly to cell damage. Our data indicate that inhibition of early $\alpha$-syn aggregation events would consequently prevent all $\alpha$-syn oligomer related toxicities. This has important implications for the development of disease-modifying drugs for the treatment of PD and other synucleinopathies.
\end{abstract}

Key words: Parkinson's disease; neurodegeneration; $\alpha$-synuclein; pore-formation; oligomers; toxicity

\section{Introduction}

Parkinson's disease (PD) is pathologically characterized by a selective loss of dopaminergic neurons in the substantia nigra and aggregated protein deposits termed Lewy bodies (Dauer and Przedborski, 2003). The main component of these intracellular deposits is aggregated $\alpha$-synuclein ( $\alpha$-syn) (Goedert, 2001). Gene multiplication in the $\alpha$-syn gene (Singleton et al., 2003; ChartierHarlin et al., 2004) and missense mutations (Polymeropoulos et al., 1997; Kruger et al., 1998; Zarranz et al., 2004) are linked to familial forms of PD. This supports the importance of $\alpha$-syn in the pathogenesis of PD.

In vitro studies revealed that $\alpha$-syn aggregation is a nucleation-dependent process that occurs in a process ranging from monomer via oligomers to fibrils (Wood et al., 1999; Conway et al., 2000).

There is a growing body of evidence suggesting that the prefibrillar oligomers and protofibrils, rather than mature fibrils of

\footnotetext{
Received March 22, 2007; accepted June 21, 2007.

We are grateful to P. Kahle and C. Haass for providing $\alpha$-syn plasmids and to F. Gillardon for suggestions concerning this manuscript. We also thank $S$. Eder for exquisite technical support for calcium measurements. The excellent technical assistance of P. Anding, S. Finger, W. Lemmer, and M. Palchauchdhuri is gratefully acknowledged.

Correspondence should be addressed to either Karin Danzer or Marcus Kostka, Central Nervous System Research, Boehringer Ingelheim Pharma GmbH, Birkendorferstrasse 65, 88397 Biberach, Germany. E-mail: Karin.Danzer@bc.boehringer-ingelheim.com or Marcus.Kostka@bc.boehringer-ingelheim.com.

D0I:10.1523/JNEUROSCI.2617-07.2007

Copyright $\odot 2007$ Society for Neuroscience $\quad 0270-6474 / 07 / 279220-13 \$ 15.00 / 0$
}

$\alpha$-syn, are the pathogenic species (Conway et al., 2000; Goldberg and Lansbury, 2000; Masliah et al., 2000; Auluck et al., 2002; Bucciantini et al., 2002, 2004; Gosavi et al., 2002; Kayed et al., 2003, 2004; Park and Lansbury, 2003; Bodner et al., 2006; ElAgnaf et al., 2006).

To date there are several protocols on oligomer preparation existing (Kayed et al., 2003; Lashuel and Grillo-Bosch, 2005). Whether these methods end up in the same type of oligomers is currently not clear. If and how oligomers differ structurally from each other on a single-particle level is not known. More importantly, biological effects of different types of oligomers on cells have not been studied directly. More importantly, the question arises whether different types of oligomers induce different biological effects on cells.

To address these questions, we developed novel standardized methods of $\alpha$-syn oligomer generation and compared the samples directly on a single-particle level. We applied fluorescence intensity distribution analysis (FIDA) (Kask et al., 1999, 2000; Zemanova et al., 2004; Levin et al., 2005) in a confocal singlemolecule detection system and compared our results with the fluorescence-independent method atomic force microscopy (AFM).

We exposed these differently generated oligomers to cells to investigate whether different types of oligomers have various biological effects on cells. We examined their respective actions on cytosolic calcium levels and their ability to seed intracellular ag- 
gregation of $\alpha$-syn in SH-SY5Y cells [overexpressing $\alpha$-syn and SH-SY5Y cells with endogenous $\alpha$-syn as well as in primary neurons]. This study aims to elucidate the biological effects that might also occur in patients with PD or other synucleinopathies. The identification of pathologically relevant $\alpha$-syn oligomer species therefore forms the basis for the identification of structural targets for antiaggregatory compounds that will be of great importance to prevent these amyloidogenic diseases.

\section{Materials and Methods}

\section{Materials}

All chemicals used were purchased from Sigma (Munich, Germany) unless stated otherwise.

\section{Expression and purification of recombinant wild-type $\alpha$-syn}

Expression and purification was performed as described previously by Nuscher et al. (2004). Briefly, pET-5a/ $\alpha$-syn wild-type (wt) plasmid (a kind gift from Christian Haas and Philipp Kahle, LMU Munich, Munich, Germany) was used to transform Escherichia coli BL21(DE3) pLysS (Novagen, Madison, WI). Expression was induced with isopropyl- $\beta$-Dthiogalactopyranose (Promega, Mannheim, Germany) for $4 \mathrm{~h}$. Cells were harvested, resuspended in $20 \mathrm{~mm}$ Tris and $25 \mathrm{~mm} \mathrm{NaCl}, \mathrm{pH} 8.0$, and lysed by freezing in liquid nitrogen followed by thawing. After $30 \mathrm{~min}$ of boiling, the lysate was centrifuged at $17600 \times g$ for $15 \mathrm{~min}$ at $4^{\circ} \mathrm{C}$. Supernatant was filtered through a $0.22 \mu \mathrm{m}$ filter (Millex-GV; Millipore, Bedford, MA) before being loaded onto a HiTrap Q HP column ( $5 \mathrm{ml}$; Amersham Biosciences, Munich, Germany) and eluted with a 25 to $500 \mathrm{~mm} \mathrm{NaCl}$ salt gradient. The pooled $\alpha$-syn peak was passed over a Superdex $200 \mathrm{HR}$ 10/30 size exclusion column (Amersham Biosciences) using $20 \mathrm{~mm}$ Tris

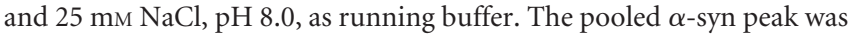
concentrated using Vivaspin columns [molecular weight cutoff (MWCO), $5 \mathrm{kDa}$; Vivascience, Stonehouse, UK] and equilibrated to water. The protein concentration was determined using a BCA proteinquantification kit (Pierce, Rockford, IL). Aliquots were lyophilized and stored at $-80^{\circ} \mathrm{C}$.

\section{Fluorescent labeling of $\alpha$-syn}

Protein labeling with the aminoreactive fluorescent dye Alexa Fluor-488O-succinimidylester (Alexa-488; Invitrogen, Eugene, OR) was performed according to the manufacturer's manual. Unbound fluorophores were separated by filtration steps in PD10 columns (Sephadex G25; Amersham Biosciences) equilibrated with $50 \mathrm{~mm}$ sodium phosphate, $\mathrm{pH}$ 7.0. Quality control of labeled $\alpha$-syn was performed by mass spectrometry and by fluorescence correlation spectroscopy (FCS) measurements on an Insight Reader (Evotec Technologies, Hamburg, Germany). The typical labeling ratio, was approximately two dye molecules per $\alpha$-syn molecule. To remove preformed aggregates, the stock solution of labeled $\alpha$-syn was subjected to size exclusion chromatography (Sephadex 200; Amersham Biosciences)

\section{Preparation of $\alpha$-syn oligomers}

Long incubation protocol (types A1 and A2). Type A oligomers were prepared by dissolving lyophilized protein in $50 \mathrm{~mm}$ sodium phosphate buffer, pH 7.0, containing $20 \%$ ethanol to a final concentration of $7 \mu \mathrm{M}$. In case of type $\mathrm{A} 2$ oligomers, $10 \mu \mathrm{M} \mathrm{FeCl}{ }_{3}$ (J.T. Baker, Griesheim, Germany) were additionally added, whereas type Al oligomers were prepared without addition of $\mathrm{FeCl}_{3}$. After $4 \mathrm{~h}$ of shaking (GFL, Burgwedel, Germany), both types of oligomers were relyophilized and resuspended with one-half of starting volume in $50 \mathrm{~mm}$ sodium phosphate buffer, $\mathrm{pH}$ 7.0, containing $10 \%$ ethanol. This was followed by shaking for $24 \mathrm{~h}$ (stage 5, thermomixer 5436; Eppendorf, Wesseling-Berzdorf, Germany) at room temperature (RT) with open lids to evaporate residual ethanol. After $6 \mathrm{~d}$ incubation of both oligomers types at RT with closed lids, oligomers were used for characterization studies (e.g., calcium influx and toxicity experiments). Alexa Fluor-488-O-succinimidylester-labeled oligomers were prepared in the same manner as nonlabeled oligomers by using Alexa-488 conjugated monomers.

Stirring incubation protocol (types B1 and B2). Type B oligomers were prepared similarly to type A oligomers by dissolving lyophilized protein in $50 \mathrm{~mm}$ sodium phosphate buffer, $\mathrm{pH} 7.0$, containing $20 \%$ ethanol to a final concentration of $7 \mu \mathrm{M}$. In case of type B2 oligomers, $10 \mu \mathrm{M} \mathrm{FeCl}$ was additionally added, whereas type $\mathrm{B} 1$ oligomers were prepared without addition of $\mathrm{FeCl}_{3}$. After $4 \mathrm{~h}$ of shaking (GFL), both oligomer types were relyophilized and resuspended with one-half of starting volume of 50 mm sodium phosphate buffer, pH 7.0, containing 10\% ethanol. Additionally, after this procedure, oligomers were stirred (RCT basic; IKA Labortechnik, Staufen, Germany) with open lids using a Teflon-coated microstirrer bar (Fisher, Pittsburgh, PA) for 24 h at RT. Alexa-488labeled oligomers were prepared in the same manner as nonlabeled oligomers by using Alexa- 488 fluorescent monomer.

Spin concentration protocol (types C1 and C2). Type C oligomers were also prepared similarly to type A oligomers by dissolving lyophilized protein in $50 \mathrm{~mm}$ sodium phosphate buffer, $\mathrm{pH} 7.0$, containing $20 \%$ ethanol to a final concentration of $7 \mu \mathrm{M}$. In case of type C2 oligomers, 10 $\mu \mathrm{M} \mathrm{FeCl}$ was additionally added, whereas oligomers type $\mathrm{C} 1$ were prepared without addition of $\mathrm{FeCl}_{3}$. After overnight incubation at room temperature under continuously shaking (GFL), oligomers were concentrated using ultracentrifugation (VivaSpin 500 columns; Vivascience). The oligomers were separated from monomer using a MWCO $30 \mathrm{kDa}$ filter. The oligomers were retained while the monomeric protein passed through the filter as verified by FCS. Alexa-488-labeled oligomers were prepared in the same manner as nonlabeled oligomers by using Alexa488-conjugated monomers.

\section{Atomic force microscopy}

Sample preparation for AFM was performed at RT. Typically, 3-6 $\mu$ l of different oligomers diluted in corresponding buffers to a working concentration of $1 \mu \mathrm{M}$ were applied to a freshly cleaved muscovite mica substrate (Ted Pella, Redding, CA) and incubated for $1 \mathrm{~min}$. The mica surface was then rinsed with $7 \times 200 \mu$ lof double-processed tissue culture water (Sigma) to remove salts and loosely bound proteins. AFM images were recorded on a MultiModeTM SPM (Digital Instruments, Santa Barbara, CA) equipped with an E-Scanner using etched silicon NanoProbes (model RTESP; Veeco Instruments, Mannheim, Germany). All measurements were performed in the tapping mode with scan rates of $\sim 0.5 \mathrm{~Hz}$. Images were processed using NanoScope software (Digital Instruments).

\section{Confocal single-particle analysis}

FIDA measurements were performed on an Insight Reader (Evotec Technologies) with dual-color excitation at 488 and $633 \mathrm{~nm}$, using a $40 \times 1.2$ numerical aperture microscope objective (Olympus, Tokyo, Japan) and a pinhole diameter of $70 \mu \mathrm{m}$ at the FIDA setting. Excitation power was 200 $\mu \mathrm{W}$ at $488 \mathrm{~nm}$. Measurement time was $10 \mathrm{~s}$. Scanning parameters were set to $100 \mu \mathrm{m}$ scan-path length, $50 \mathrm{~Hz}$ beam-scanner frequency, and $2000 \mu \mathrm{m}$ positioning-table movement. This is equivalent to $\sim 10 \mathrm{~mm} / \mathrm{s}$ scanning speed. All measurements were performed at RT. The fluorescence signal was analyzed by FIDA using FCSPP evaluation software version 2.0 (Evotec Technologies). Fluorescence from the fluorophore Alexa-488 was recorded with a single-photon detector. Photons were summed over time intervals of constant length (bins) using a bin length of $40 \mu$ s (Kask et al., 1999, 2000). Based on previous results, the obtained data were analyzed by a three-component fit with two components fixed to a particle brightness $\mathrm{Q}$ of 20 and 50, respectively. For the threshold setting, nonaggregated reference samples were used. This singlemolecule detection technology allows highly sensitive analysis of protein aggregation by slight changes in the brightness of individual particles. FIDA is able to distinguish between differently bright species and, as such, gives indirect information about particle sizes.

\section{Cell culture}

SH-SY5Y human dopaminergic neuroblastoma cells were maintained at $37^{\circ} \mathrm{C}$ in $5 \% \mathrm{CO}_{2}$ in high-glucose DMEM (PAA Laboratories, Pasching, Austria) supplemented with $15 \%$ fetal bovine serum (Invitrogen) and 4 mu glutamine (Invitrogen).

To generate stable cell lines, SH-SY5Y cells were transfected using Metafectene (Cambio, Cambridge, UK) with pcDNA 3.1neo encoding $\alpha$-syn[wt], $\alpha$-syn[A30P], or $\alpha$-syn[A53T] (plasmids were a kind gift from C. Haas and P. Kahle. As mock vector controls, SH-SY5Y cells were 
transfected with plasmid pUHD15.1 encoding the transactivator protein for the tetracycline inducible expression system (Clontech, SaintGermain-en-Laye, France). Mock-transfected cells served as cells with endogenous level of $\alpha$-syn.

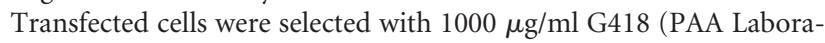
tories) for 2-3 weeks until colonies emerged. Stable transfectants established from these colonies were tested for their $\alpha$-syn expression levels using immunofluorescence and Western blot analyses.

\section{Cortical cell culture}

Neuron-enriched cerebral cortical cells were prepared from embryonic brains (embryonic day 14) of mice. Cortices were dissected from embryonic brain and the meninges was removed. The cells were dissociated by trypsinization and tituration. The dissociated cells were resuspended in serum-free B27/neurobasal medium (Invitrogen) and plated at a density of $1.25 \times 10^{5}$ cells $/ \mathrm{cm}^{2}$ on dishes precoated with poly-D-lysin/laminin. Cells were maintained at $37^{\circ} \mathrm{C}$ in the presence of $10 \% \mathrm{CO}_{2} / 90 \%$ air in a humidified incubator. The medium was changed every third day.

\section{Measurement of intracellular $\mathrm{Ca}^{2+}$}

FLIPR. For intracellular $\mathrm{Ca}^{2+}$ measurements using fluorescence imaging with a fluorescent imaging plate reader (FLIPR), primary cortical neurons were seeded at a density of $1.25 \times 10^{5}$ cells $/ \mathrm{cm}^{2}$ on 384 -well, black clear-bottom microtiter plates (BD Biosciences, Heidelberg, Germany) precoated with poly-D-lysin/laminin and cultured as described above. After $7 \mathrm{~d}$, cortical neurons were used for $\mathrm{Ca}^{2+}$ measurements. Mocktransfected SH-SY5Y cells and $\alpha$-syn[wt], [A30P], or [A53T] mutants were seeded into collagen I coated 384-well, black clear-bottom microtiter plates (BD Biosciences) at a density of 6000 cells/well and cultured overnight. At the day of experiment, cells were washed with Ringer buffer [containing (in mM) $130 \mathrm{NaCl}, 5 \mathrm{KCl}, 1 \mathrm{CaCl}_{2}, 1 \mathrm{MgCl}_{2}, 2 \mathrm{KH}_{2} \mathrm{PO}_{4}, 5$ glucose, and 20 HEPES] and loaded for $60 \mathrm{~min}$ with $2 \mu \mathrm{M}$ the cellpermeable Fluo-4 AM (Teflabs, Austin, TX) in Ringer buffer containing $0.1 \%(\mathrm{w} / \mathrm{v})$ pluronic acid F127 (Invitrogen). After removal of the fluorophore loading solution, cell layers were washed with Ringer buffer, incubated at room temperature for $30 \mathrm{~min}$, and washed again. The cell plates were then loaded into an FLIPR (TETRA TM; Molecular Devices, Wokingham, UK) together with a separate 384-well plate containing oligomers and controls. Treatment of cells was performed with the following final concentrations: $7 \mu \mathrm{M}$ oligomer types A1 and A2 (referring to moles of monomer starting concentration), $500 \mu \mathrm{g} / \mathrm{ml}$ gramicidin $\mathrm{D}$, and $1.5 \mu \mathrm{M}$ ionomycin as positive controls. Test compounds were distributed in a randomized pattern to minimize any cell plating effects caused by well position. The FLIPR was programmed to transfer the test compounds and solvents simultaneously to all 384 wells $10 \mathrm{~s}$ after commencement of recording of fluorescence [expressed as relative fluorescence units (RFUs)]. Fluorescence was excited at $488 \mathrm{~nm}$ and emission was measured at $510-560 \mathrm{~nm}$. The duration of recording was $10 \mathrm{~min}$. Data are displayed as negative control-corrected values, meaning signal response to oligomers including subtraction of corresponding solvent controls. The resulting signals were quantified by taking the maximum peak height of recording duration using Screenworks 1.2.0.73 software and are expressed as mean \pm SEM. Treatment effects were analyzed by unpaired $t$ test for each cell line. For the SH-SY5Y cell lines, $p$ values were additionally adjusted for multiple testing using the Bonferroni correction method. A $p$ value $<5 \%$ was considered statistically significant. Differences $(\Delta)$ between treated and untreated cell lines were quantified by differences of mean values and corresponding $95 \%$ confidence intervals (CIs). All cell lines were separately analyzed. For investigation of calcium source, calcium was omitted from the Ringer buffer and experiments were performed as described above. To demonstrate a calcium ion channel-independent effect of oligomers, $20 \mu \mathrm{M}$ cobalt, a nonspecific calcium-channel blocker, was applied to cells $5 \mathrm{~min}$ before the application of oligomers. Experimental setup was the same as described above.

Fluorescence imaging with confocal microscopy. SH-SY5Y cells overexpressing $\alpha$-syn[wt] were seeded into collagen I-coated 96-well, black $\mu$-clear-bottom microtiter plates (Greiner Bio-One, Frickenhausen, Germany) at a density of 7500 cells/well and cultured overnight. Cortical neurons were seeded at a density of $6 \times 10^{4}$ cells $/ \mathrm{cm}^{2}$ on 96 -well, black $\mu$-clear-bottom microtiter plates (Greiner Bio-One) precoated with poly-D-lysin/laminin and cultured as described above. After $7 \mathrm{~d}$, cortical neurons were used for $\mathrm{Ca}^{2+}$ measurements.

Cells were washed with Ringer buffer [containing (in mM) $130 \mathrm{NaCl}, 5$ $\mathrm{KCl}, 1 \mathrm{CaCl} 2,1 \mathrm{MgCl} 2,2 \mathrm{KH} 2 \mathrm{PO} 4,5$ glucose, and $20 \mathrm{HEPES}$ ] and loaded with $2 \mu \mathrm{M}$ the cell-permeable Fluo-4 AM (Teflabs) in Ringer buffer containing $0.1 \%(\mathrm{w} / \mathrm{v})$ pluronic acid (Invitrogen) at $37^{\circ} \mathrm{C}$ for $60 \mathrm{~min}$. After removal of the fluorophore loading solution, the cells were washed with Ringer buffer, incubated at room temperature for $30 \mathrm{~min}$, and washed again. The imaging system consisted of an inverted confocal microscope (DM IRBE; Leica, Wetzlar, Germany) equipped with a Leica $63 \times$ objective. Fluorescence excitation was performed with a $488 \mathrm{~nm}$ argon ion laser and emitted fluorescence $(505 \mathrm{~nm}<\lambda<530 \mathrm{~nm}$ ) was imaged by a scan head (Leica TCS SP). Time-lapse pictures (one frame per $2.5 \mathrm{~s}$ ) were captured using the Leica confocal software package and fluorescence intensities were measured from regions of interest centered on individual cells. Signals were expressed in RFUs. Treatment of cells was performed with the following final concentrations: $7 \mu \mathrm{M}$ monomer, $7 \mu \mathrm{M}$ oligomer types $\mathrm{A} 1$ and $\mathrm{A} 2$ (referring to moles of monomer starting concentration), and $6 \mu \mathrm{M}$ ionomycin as a positive control. Treatments were applied by pipetting a fixed aliquot of $50 \mu \mathrm{l}$ into the recorded well directly above the objective. The duration of recording was 150 or $300 \mathrm{~s}$. The 10 -fold accelerated time-lapse videos were made using Windows Movie Maker software (Microsoft, Redmond, WA).

\section{Measurement of membrane potential changes using FLIPR}

Primary cortical neurons were seeded at a density of $1.25 \times 10^{5} \mathrm{cells} / \mathrm{cm}^{2}$ on 384-well, black clear-bottom microtiter plates (BD Biosciences) precoated with poly-D-lysin/laminin and cultured as described above. After $7 \mathrm{~d}$, cortical neurons were used for measurements of membrane potential. FLIPR membrane potential assay kit was performed according to the manufacturers instructions. Briefly, cells were washed one time with assay buffer ( $1 \times$ HBSS with 20 mM HEPES, pH 6). Twenty microliters of loading buffer (catalog \#8034; Molecular Devices) reconstituted as described in the product insert (final concentration, $20 \mu \mathrm{M}$ ) was added to each well. Cell plates were incubated for $30 \mathrm{~min}$ at $37^{\circ} \mathrm{C}$. The cell plates were then loaded into an FLIPR (TETRA TM; Molecular Devices) together with a separate 384-well plate containing oligomers and controls. Treatment of cells was performed with the following final concentrations: $7 \mu \mathrm{M}$ oligomer types A1 and A2 (referring to moles of monomer starting concentration), and $500 \mu \mathrm{g} / \mathrm{ml}$ gramicidin $\mathrm{D}$ as positive control. The FLIPR was programmed to transfer the test compounds and solvents simultaneously to all 384 wells $15 \mathrm{~s}$ after commencement of recording of fluorescence (expressed as RFUs). Fluorescence was excited at $(510 \mathrm{~nm}<$ $\lambda<545 \mathrm{~nm}$ ) and emission was measured at (565 nm $<\lambda<625 \mathrm{~nm}$ ). Duration of recording was $10 \mathrm{~min}$. Data are displayed as negative control corrected values, meaning signal response to oligomers including subtraction of corresponding solvent controls. The resulting signals were quantified by taking the maximum peak height of recording duration using Screenworks 1.2.0.73 software and are expressed as mean \pm SEM. Treatment effects for primary neurons were analyzed by one-sample $t$ tests versus the hypothetical value 0 and quantified by mean values of differences $(\Delta)$ and corresponding $95 \%$ CIs.

\section{Cell treatment and immunofluorescence staining}

To investigate toxic effects or seeding properties of different oligomer preparations, SH-SY5Y cells overexpressing mutant $\alpha$-syn[A53T] were seeded at 5000 cells/well using collagen I-coated 384-well, black clearbottom microtiter plates (BD Biosciences). On the next day, cells were treated with $7 \mu \mathrm{M}$ (referring to moles of monomer) of different oligomers and the same volume of the corresponding solvent controls. After $2 \mathrm{~h}$ treatment, oligomers were diluted 1:2 in culture medium for subsequent overnight treatment.

The treatment was stopped after overnight incubation using $2 \%$ formaldehyde and $1 \mu \mathrm{M}$ Hoechst 33342 (Invitrogen) in PBS as fixation solution. After washing, the cells were permeabilized and unspecific binding sites were blocked using $0.05 \%$ saponin and $1 \%$ bovine serum albumin in PBS. After washing, the primary antibody [rabbit antibody against activated caspase-3 (Asp175; Cell Signaling Technology, Beverly, MA) or 

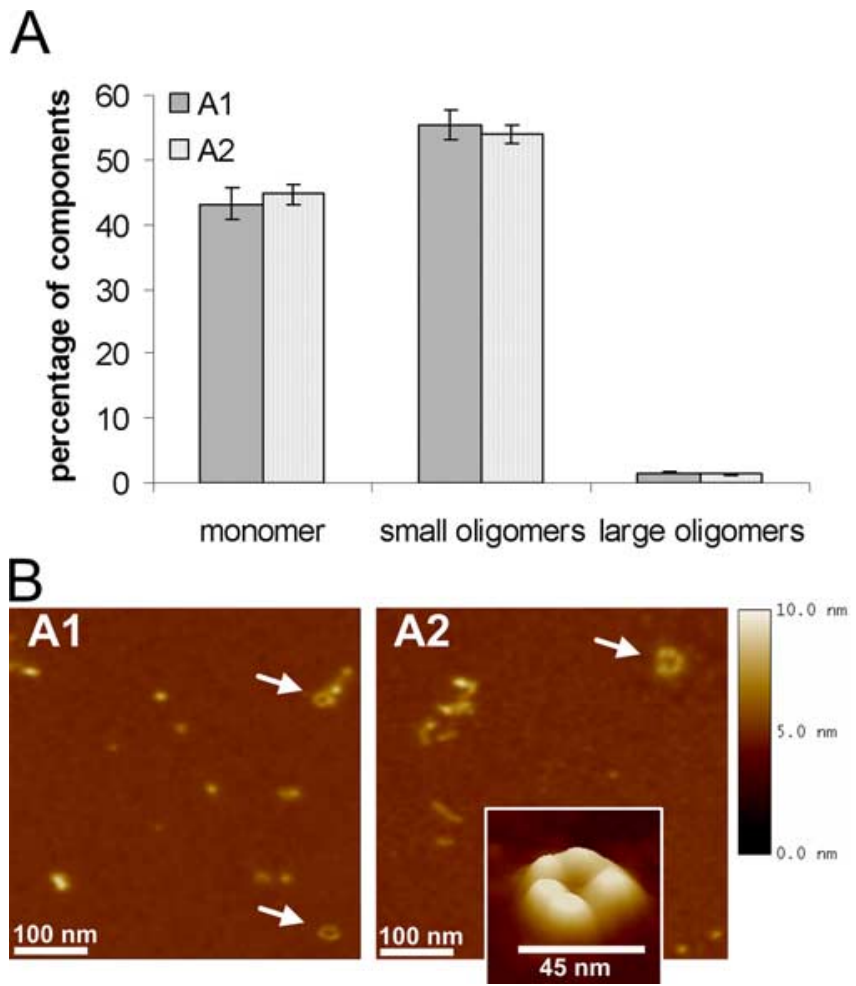

Figure 1. Characterization of long-term incubation of $\alpha$-syn oligomers (types $\mathrm{A} 1$ and A2). $\boldsymbol{A}$, FIDA analysis of two oligomeric $\alpha$-syn forms generated after long-term incubation ( $6 \mathrm{~d}$ ) in 50 $\mathrm{mm}$ sodium phosphate buffer. The influence of ferrous chloride has been worked out (type A1 without ferrous chloride and type $A 2$ with ferrous chloride). The mean \pm SEM of five measurements are shown. $\boldsymbol{B}$, AFM images $(500 \times 500 \mathrm{~nm})$ of type A1 and A2 oligomeric $\alpha$-syn forms generated after long-term incubation ( $6 \mathrm{~d}$ ) in $50 \mathrm{~mm}$ sodium phosphate buffer. Section analysis revealed globular or protofibrillar oligomers from 2 to $6 \mathrm{~nm}$ in height. Also, annular structures (arrows) were found in both oligomer types A1 and A2. AFM images are representative examples of several AFM images of independent oligomer preparations.

rabbit antibody against $\alpha$-syn (ASY-1; a kind gift from Poul Henning Jensen, University of Aarhus, Denmark); described by Jensen et al. (2000)] was added for $1 \mathrm{~h}$ at $37^{\circ} \mathrm{C}$, followed by another washing step and incubation with the secondary antibody (anti-rabbit antibody labeled with Alexa-Fluor 647; Invitrogen) for $1 \mathrm{~h}$ at RT. After a final washing step, $50 \mu \mathrm{l} /$ well remained as residual volume.

Western blotting of SH-SY5Y cell extracts

SH-SY5Y cells were scraped from $100 \mathrm{~mm}$ dishes and washed by centrifugation and resuspension in cold PBS. The cells were resuspended in lysis buffer (250 mм Tris, 750 mм NaCl, 10 mм EDTA, 1\% NP-40, $25 \mu \mathrm{g} / \mathrm{ml}$ leupeptin, protease inhibitor mixture, $\mathrm{pH}$ 7.4) and incubated on ice for $30 \mathrm{~min}$. After centrifugation at $1500 \times g$ for $10 \mathrm{~min}$, protein concentrations of supernatants were quantified using the BCA assay (Pierce, Rockford, IL). Lysates (30 $\mu \mathrm{g}$ of protein) were resolved by electrophoresis on a $4-12 \%$ Bis-Tris gradient gel (NuPAGE; Novex Bis-Tris Gel; Invitrogen) according to manufacturers instructions using NuPAGE MES buffer. After transfer to nitrocellulose membrane (Protran; Whatman, Dassel, Germany) the blot was blocked for $1 \mathrm{~h}$ at RT with blocking buffer (I-block; Tropix, Bedford, MA). The blot was probed with ASY-1 antibody (1:500; a kind gift from Poul Henning Jensen) or anti-GAPDH (1:1000; HyTest, Turku, Finland) for $1 \mathrm{~h}$ at RT. Bands were detected using alkaline phosphatase-conjugated secondary antibodies (1:5000; Tropix) and imaged with VersaDoc imaging system (Bio-Rad, Munich, Germany).

Measurement of the assay plates in the IN Cell Analyzer 3000 Automated confocal fluorescence microscopy using the IN Cell Analyzer 3000 (GE Healthcare Bio-Sciences, Little Chalfont, UK) has been described in detail (Haasen et al., 2006; Wolff et al., 2006). For our experi-
A
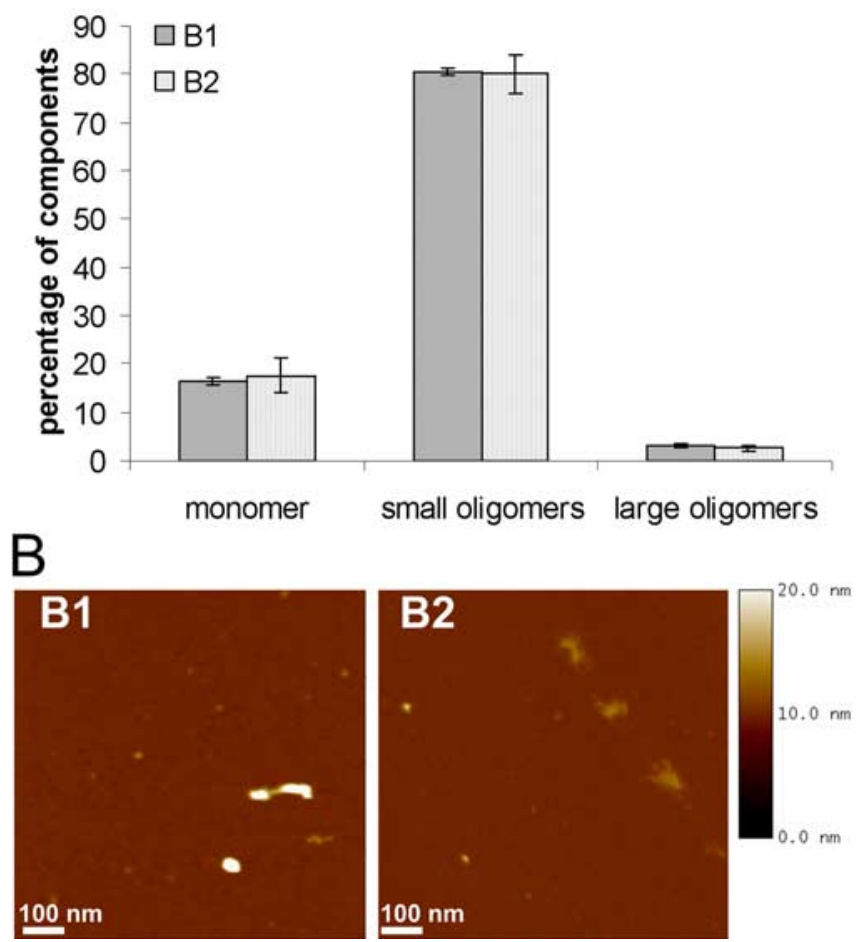

Figure 2. Characterization of $\alpha$-syn oligomer types B1 and B2 generated with stirring bars. $A$, Single-particle analysis revealed two oligomeric forms generated with stirring bars. The influence of ferrous chloride has been worked out (type B1 without ferrous chloride and type B2 with ferrous chloride). $\boldsymbol{B}$, AFM images ( $\left.1 \mu \mathrm{m}^{2}\right)$ of two oligomeric forms generated with stirring bars. Oligomers appeared as heterogeneous population with particles from $3 \mathrm{to} 23 \mathrm{~nm}$ in height using section analysis. Oligomer type B1 appeared in a more compact spherical form than oligomer type B2. AFM images are representative examples of several AFM images of independent oligomer preparations.

ments, we used the 364 laser line combined with a 450BP25 emission filter for Hoechst 33342, the $647 \mathrm{~nm}$ laser line combined with a 695BP55 emission filter for Alexa Fluor 647, and the $488 \mathrm{~nm}$ laser line with a 535BP45 emission filter for Alexa Fluor 488. Fluorescence emission was recorded separately in the blue, red, and green channels, applying a flatfield correction for inhomogeneous illumination of the scanned area for each of the three channels.

\section{Image analysis}

Images stained for activated caspase- 3 were analyzed using the nuclear trafficking (TRF2) algorithm of the IN Cell Analyzer 3000. Briefly, the algorithm identified the nuclei as pixel accumulations above a specified intensity threshold in the blue (nuclear) channel image. The number of nuclei correspond to the absolute cell number. In a specified dilated "cytoplasmic" mask region around these nuclei, the algorithm then searched for cells above a defined threshold in the red channel image, identifying cells stained for activated caspase-3. The percentage of positive cells for each image was calculated as follows: the percentage of positive cells $=$ (number of positive cells in signal channel/number of total cells in nuclear channel) $\times 100$. For each treatment, the percentage of positive cells and the number of total cells were normalized to the respective solvent controls to give the percentage of control values. The mean and SEM for each analysis were calculated from the indicated number of images. Statistical significance was determined by unpaired $t$ test with $p<0.05$.

\section{Statistical analysis}

Statistical analysis was performed as indicated as mentioned in the respective sessions for calcium measurements, measurement of membrane potential, and image analysis using IN Cell Analyzer 3000. 

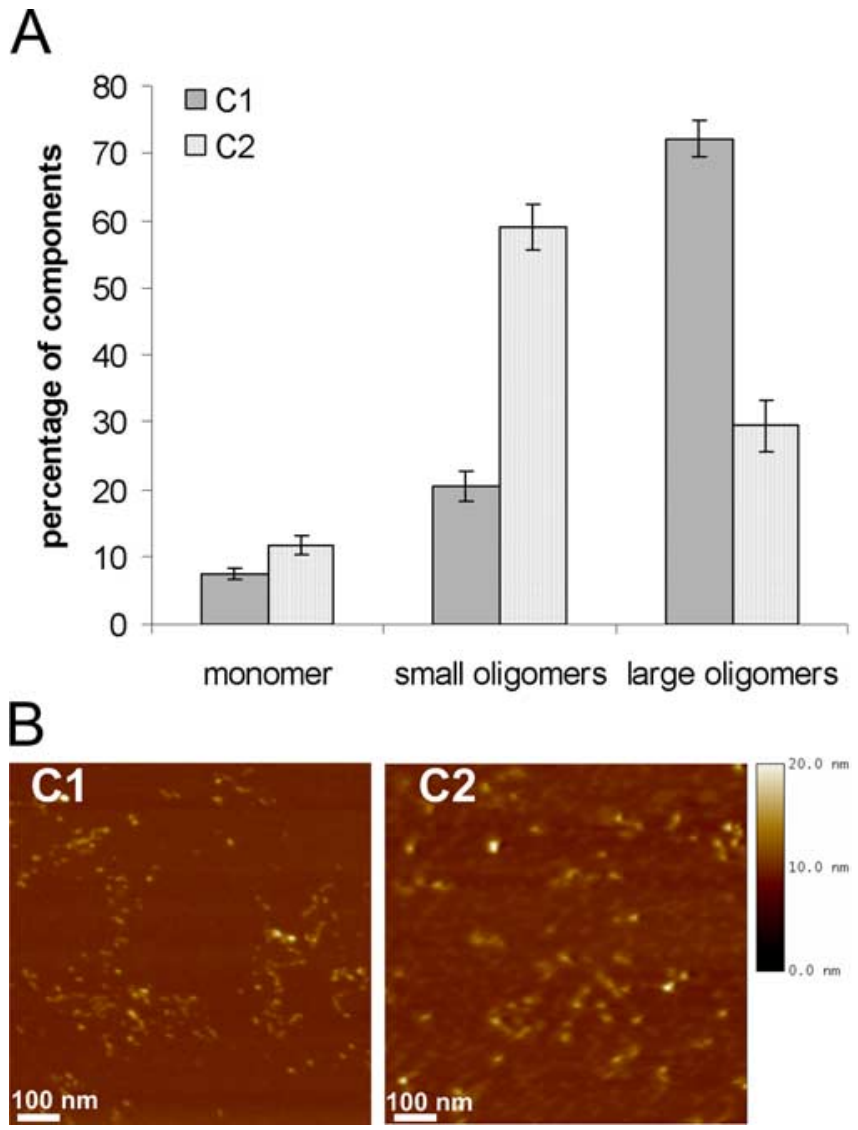

Figure 3. Characterization of $\alpha$-syn oligomers (types (1 and (2). $\boldsymbol{A}$, Single-particle analysis of two oligomeric $\alpha$-syn forms generated by overnight incubation and ultrafiltration. The influence of ferrous chloride has been analyzed (type C 1 without ferrous chloride and type $C 2$ with ferrous chloride). $\boldsymbol{B}$, AFM images (1 $\mu \mathrm{m}^{2}$ ) of two oligomeric $\alpha$-syn forms generated by overnight incubation and ultracentrifugation. Images showed globular and protofibrillar oligomer structures 4-10 nm in height. Using AFM analysis, there were no significant morphological differences detectable between oligomer type C1 and oligomer type C2. AFM images are representative examples of several AFM images of independent oligomer preparations.

\section{Results}

Aggregation of $\alpha$-syn plays an important role in the pathogenesis of PD and other synucleinopathies. To characterize oligomers on a single particle level and to investigate their biological effects on both human neuroblastoma SH-SY5Y cells and primary cortical neurons, we developed three novel protocols for oligomer generation based on published observations. For the first time we compared the oligomers directly in shape, morphology, and size using two single-particle analysis methods. Finally, we investigated their bioactivity on cultured human cells.

The combination of ethanol and iron is sufficient to induce $\alpha$-syn oligomerization at very low protein concentrations (M. Kostka, T. Högen, K. Danzer, and A. Giese, unpublished observation). To reduce ethanol concentrations that would interfere with subsequent cell-culture experiments and to increase the oligomer yield, the aggregation conditions have been adapted and optimized. In the experiments described here, we compared three different approaches.

First, we incubated oligomers for a period of $6 \mathrm{~d}$ after lyophilization and resuspension in sodium phosphate buffer. This type of oligomers was termed type A. Second, based on the oligomer preparation protocol of Kayed et al. (2003), we used stirring bars to accelerate the aggregation process and to minimize ethanol concentrations concurrently. We termed this oligomer type B. In the third approach, we used ultrafiltration to concentrate oligomers for use in cell culture. This oligomer type was named type C. Based on a finding that iron increases particle size of ethanolinduced oligomers (M. Kostka, T. Högen, K. Danzer, and A. Giese, unpublished observation), we investigated the influence of iron on all three oligomer types (A, B, and C). Iron-free oligomers were termed type 1 oligomers and iron-containing oligomers type 2 .

To quantify and characterize the differently prepared oligomers, we used fluorescently labeled $\alpha$-syn in nanomolar concentrations and applied FIDA with a confocal single-molecule detection system.

\section{Characterization of $\alpha$-syn type A oligomers}

Applying FIDA to characterize our oligomers, we found in the type A oligomers that nearly half of the overall particles appeared as monomers, whereas the other half was composed of small oligomeric particles. Although type A oligomers were incubated for several days, we found only small amounts of large oligomeric particles. There was no influence of iron on the particle size observed (Fig. $1 A$ ). To confirm our FIDA results, we used AFM as a fluorescence-independent single-molecule detection system.

AFM analysis showed that oligomers in the type A preparation appeared as a heterogeneous population with globular and protofibrillar structures. Iron seemed to influence the aggregation process resulting in more extended protofibrillar structures (A2) whereas the iron-free preparation (A1) favors the generation of spherical structures (Fig. $1 B$ ). Thus, small oligomer particles observed with FIDA could be confirmed with AFM analysis when compared with section analysis of monomers. As also described by Lashuel et al. (2002b), we observed annular structures 40-45 $\mathrm{nm}$ in diameter in both preparations. Importantly, these annular structures were not found in monomer preparations (supplemental Fig. 1, available at www.jneurosci.org as supplemental material). In contrast to FIDA analysis, almost no monomers were observed in type A oligomer preparations with our experimental AFM setup.

Together, using the complementary biophysical techniques FIDA and AFM, type A oligomers generated by long-term incubation of low $\alpha$-syn concentrations appeared as small, globular and annular structures.

\section{Characterization of type B oligomers}

Type B oligomers were generated using stirring bars to facilitate ethanol evaporation. Applying FIDA for oligomer type B characterization, we found, in contrast to the type A preparation, a higher conversion rate $(80 \%)$ from monomers to small oligomers. This type B oligomer contained low monomeric percentages and only a small portion of large oligomeric particles. Additionally, there was no significant influence of iron on particle composition when comparing the FIDA analysis of the B1 and B2 oligomer preparations (Fig. 2A).

Structural insight into type B oligomers was given by AFM analysis. Height images showed that type B oligomers appeared as a heterogeneous population (Fig. $2 \mathrm{~B}$ ). Also by stirring, globular structures have been detected, but no annular structures have been observed in any preparation. In contrast to FIDA analysis, we saw an influence of iron on oligomer formation: iron-free prepared B1 oligomers appeared in a more compact spherical shape, whereas B2 oligomers prepared with iron showed up as amorphous structures.

Finally, the data demonstrate that type B oligomers were heterogeneous, globular oligomers, with low amounts of monomers and a majority of small oligomeric particles. 

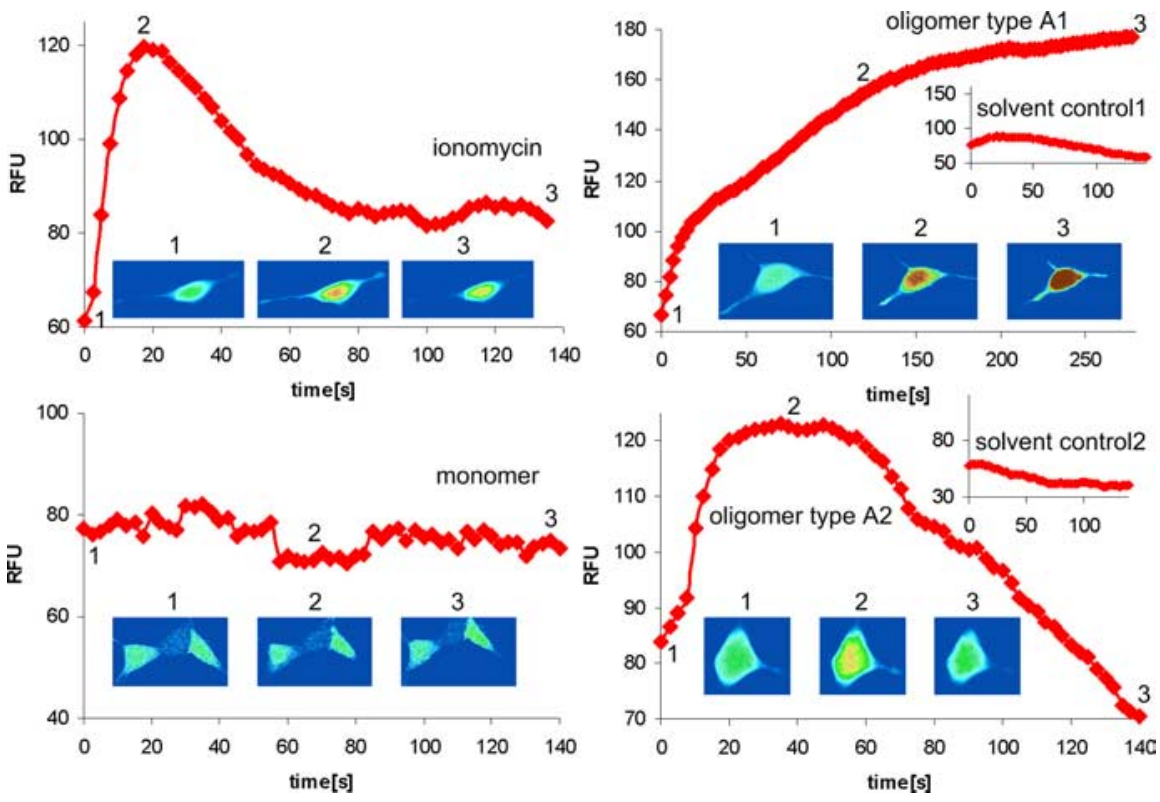

Figure 4. $\quad\left[\mathrm{Ca}^{2+}\right]$ elevation by $\alpha$-syn oligomer types A1 and A2 in SH-SY5Y cells. Traces show $\left[\mathrm{Ca}^{2+}\right]$-dependent fluorescence of single SH-SY5Y cells overexpressing $\alpha$-syn[wt] in response to $6 \mu \mathrm{m}$ ionomycin, $0.1 \mathrm{mg} / \mathrm{ml}$ monomer, and $0.1 \mathrm{mg} / \mathrm{ml} \mathrm{oligomer}$ types $\mathrm{A} 1$ and $\mathrm{A} 2$ with respective solvent controls. Oligomer types $\mathrm{A} 1$ and $\mathrm{A} 2$ evoked a clear increase in intracellular $\left[\mathrm{Ca}^{2+}\right]$. Fluorescence records illustrating typical responses to different treatments starting at the time point of application are shown. The inset images of the cell were captured at the times indicated during the trace and are depicted on a pseudocolor scale with "warmer" colors on a rainbow scale corresponding to higher fluorescence. The inset images show representatives of a single cell.
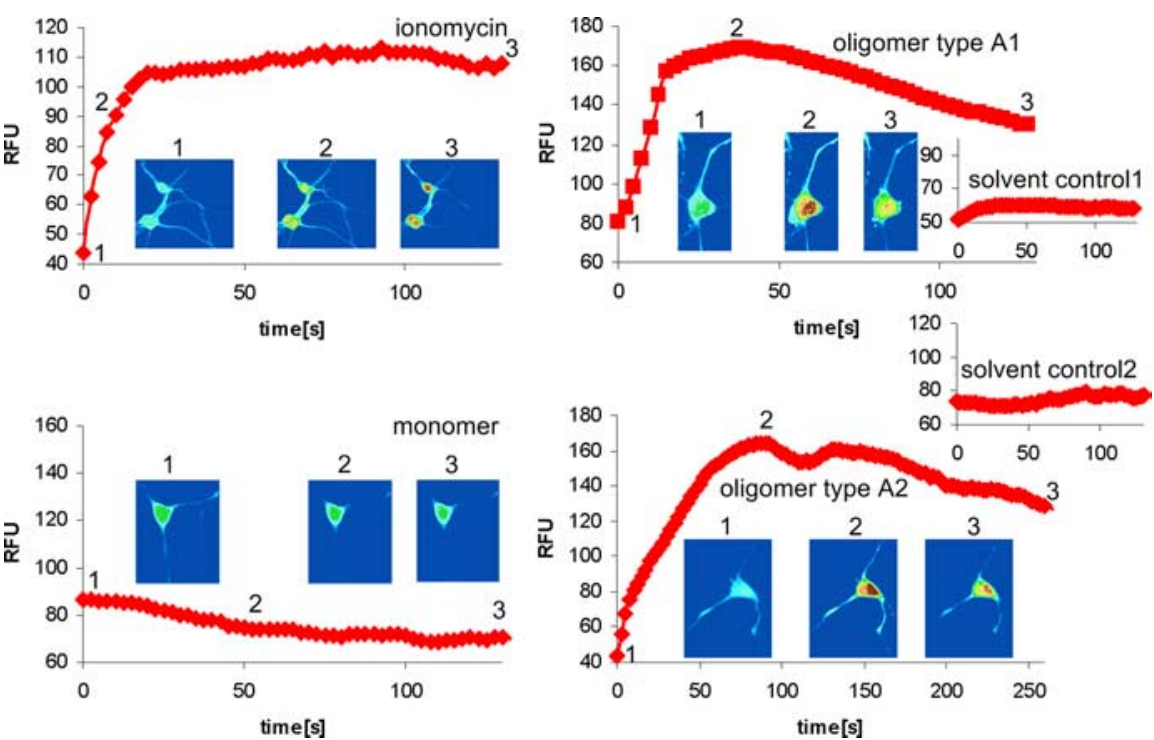

Figure 5. $\left[\mathrm{Ca}^{2+}\right]$ elevation by $\alpha$-syn oligomer types $\mathrm{A} 1$ and $\mathrm{A} 2$ in primary neurons. Traces show $\left[\mathrm{Ca}^{2+}\right]$-dependent fluorescence of single cortical neurons in response to $6 \mu \mathrm{m}$ ionomycin, $0.1 \mathrm{mg} / \mathrm{ml}$ monomer, and $0.1 \mathrm{mg} / \mathrm{ml} \mathrm{oligomer} \mathrm{types} \mathrm{A1} \mathrm{and} \mathrm{A2}$ with respective solvent controls. Oligomer types $\mathrm{A} 1$ and $\mathrm{A} 2$ evoked a clear increase in intracellular $\left[\mathrm{Ca}^{2+}\right]$. Fluorescence records illustrating typical responses to the different treatments starting at the time point of application are shown. The inset images show pseudocolor representatives of a single cell, captured at the times indicated by the trace.

\section{Characterization of type $\mathrm{C}$ oligomers}

The third kind of oligomers, type C oligomers, were prepared similar to the previous preparations and combined with an ultrafiltration step after the aggregation process.

With FIDA analysis we observed only in type C preparations an effect of iron administration: type $\mathrm{C} 2$ oligomers contained three times more small oligomeric forms than iron-free preparations (C1). Additionally, oligomer types $\mathrm{C} 1$ and $\mathrm{C} 2$ also differed in the proportion of large particles. Here, large particles were present to a higher amount when compared with oligomer types A and B. Type C oligomers showed the lowest portion of monomers (Fig. 3A) among our three oligomer types, $\mathrm{A}, \mathrm{B}$, and $\mathrm{C}$.

In contrast to the confocal fluorescence technique FIDA, the AFM analysis did not illustrate morphological differences in particle composition between oligomer types $\mathrm{C} 1$ and $\mathrm{C} 2$. Both oligomer types appeared as spherical particles with homogenous distribution of globular and protofibrillar structures (Fig. $3 B$ ). No annular structures like in the preparation type A were observed.

In summary, each of our novel protocols ended up in a heterogeneous oligomer population. We showed that changes in the aggregation protocols can lead to distinct forms of oligomers. We used these different oligomers to study the cellular responses to exogenously added oligomers.

\section{Increase in intracellular calcium} mediated by type A1 and A2 oligomers It has been suggested that abnormal intracellular calcium homeostasis plays a crucial role in the pathogenesis of neurodegenerative disorders (Mattson and Chan, 2001). Moreover, we found that ironinduced oligomers were able to form pores in a synthetic bilayer pore-forming assay (M. Kostka, T. Högen, K. Danzer, and A. Giese, unpublished observation). Similarly, Volles et al. (Volles et al., 2001; Volles and Lansbury, 2002) have shown poreforming activity of $\alpha$-syn protofibrils using synthetic vesicles. Therefore, we asked whether we could detect a calcium dysregulation in cells treated with type A oligomers. In contrast to monomer samples, oligomer types A1 and A2 evoked a rapid increase within seconds in calciumdependent fluorescence in fluo-4-loaded singular SH-SY5Y cells using confocal microscopy (Fig. 4) and in an FLIPR (supplemental Fig. $3 A$, available at www. jneurosci.org as supplemental material). The increase in intracellular calcium of singular SH-SY5Y cells is also demonstrated on a time lapse video (supplemental movie 1, available at www.jneurosci.org as supplemental material). As positive controls, we used the channel-forming polypeptide ionophore gramicidin and the chelating calcium ionophore ionomycin, which allows calcium to diffuse passively through cellular membranes (Fig. 4, supplemental Fig. 3, available at www.jneurosci.org as supplemental material). To investigate whether the observed increase in intracellular calcium was dependent on cellular $\alpha$-syn-expression levels, we compared mock-transfected SH-SY5Y cells expressing endogenous $\alpha$-syn with cells stably overexpressing $\alpha$-syn [wt] or mutant $\alpha$-syn[A30P/A53T]. These cell lines exhibited comparable $\alpha$-syn expression levels com- 
pared with the endogenous control as shown in supplemental Figure 2 (available at www. jneurosci.org as supplemental material). Again, type A1 and A2 oligomers evoked a clear increase in calcium-dependent fluorescence compared with monomer and respective solvent controls. No clear differences in the calcium signal increase between mocktransfected SH-SY5Y cells and $\alpha$-synoverexpressing SH-SY5Y cells have been observed (supplemental Fig. 3, available at www.jneurosci.org as supplemental material). These data suggest that only the exogenously applied oligomers are responsible for the elevation of intracellular calcium and that the intracellular $\alpha$-syn does not contribute to the effect in the time window investigated here.

To demonstrate also for primary neurons an elevation of intracellular calcium induced by type A oligomers, we performed the same experiments as described above for SH-SY5Y cells. Using confocal microscopy, we confirmed also in primary neurons a significant increase in intracellular calcium (Fig. 5). A time lapse video of singular neurons shows also the calcium influx effect (supplemental movie 2, available at www.jneurosci.org as supplemental material). This was further confirmed by FLIPR measurements (supplemental Fig. 4, available at www.jneurosci.org as supplemental material).

To support pore formation as a possible mechanism responsible for the calcium influx, we measured the membrane potential. Indeed, oligomer types A1 and A2 showed a depolarization of the membrane potential in primary cortical neurons as also shown for gramicidin (Fig. 6).

\section{Oligomer type A-induced calcium ion influx from extracellular sources}

To discriminate whether the observed increase in intracellular calcium induced by oligomers types $\mathrm{A} 1$ and $\mathrm{A} 2$ resulted from influx of extracellular calcium or emptying of intracellular calcium stores, we reduced the extracellular calcium concentration to very low levels by using calcium-free buffer. In the absence of extracellular calcium, the treatment of endogenous $\alpha$-syn SHSY5Y cells (Fig. 7A) completely abrogated the oligomer type A1and A2-induced intracellular calcium increase. As expected, application of the channel-forming polypeptide gramicidin also no longer elicited an increase in intracellular calcium. Only ionomycin-induced calcium signals were detectable. Thus, the increase of intracellular calcium levels induced by oligomer types A1 and A2 and gramicidin resulted from extracellular sources, whereas the remaining ionomycin signal response was mediated by both influx of extracellular calcium and intracellular calcium release.

To rule out the possibility that endogenous calciumpermeable plasma membrane ion channels were affected by oligomers types A1 and A2, we added $20 \mu \mathrm{M}$ cobalt, a nonspecific calcium-channel blocker, to endogenous $\alpha$-syn SH-SY5Y cells, before application of $7 \mu \mathrm{M}$ oligomer type A1. Signal response in the presence of cobalt was of a comparable magnitude to that obtained in the absence of cobalt (Fig. $7 B$ ), suggesting that calcium influx through cobalt-sensitive calcium channels does not contribute to oligomer type A1- and A2-induced increase in intracellular calcium.

\section{Toxicity of type A oligomers}

To investigate whether type A oligomers have toxic properties, we examined caspase- 3 activation and determined cell number reduction after oligomer type A1 and A2 treatment. Because there were no biologically relevant differences in calcium response seen in SH-SY5Y cells expressing endogenous or elevated levels of $\alpha$-syn, we performed toxicity assays only in mock-transfected cells and in mutant $\alpha$-syn[A53T]-overexpressing cells.

Immunofluorescence staining for caspase-3 after oligomer type A1 treatment showed, for both mock-transfected and mutant $\alpha$-syn [A53T]-expressing SH-SY5Y cells, a significant $(p<$ $0.05)$ increase in cleaved caspase- 3 activity. Also, treatment with oligomer type A2 resulted in a significant increase of caspase- 3 activity in both cell lines, whereas the increase in caspase- 3 activity seemed to 
A

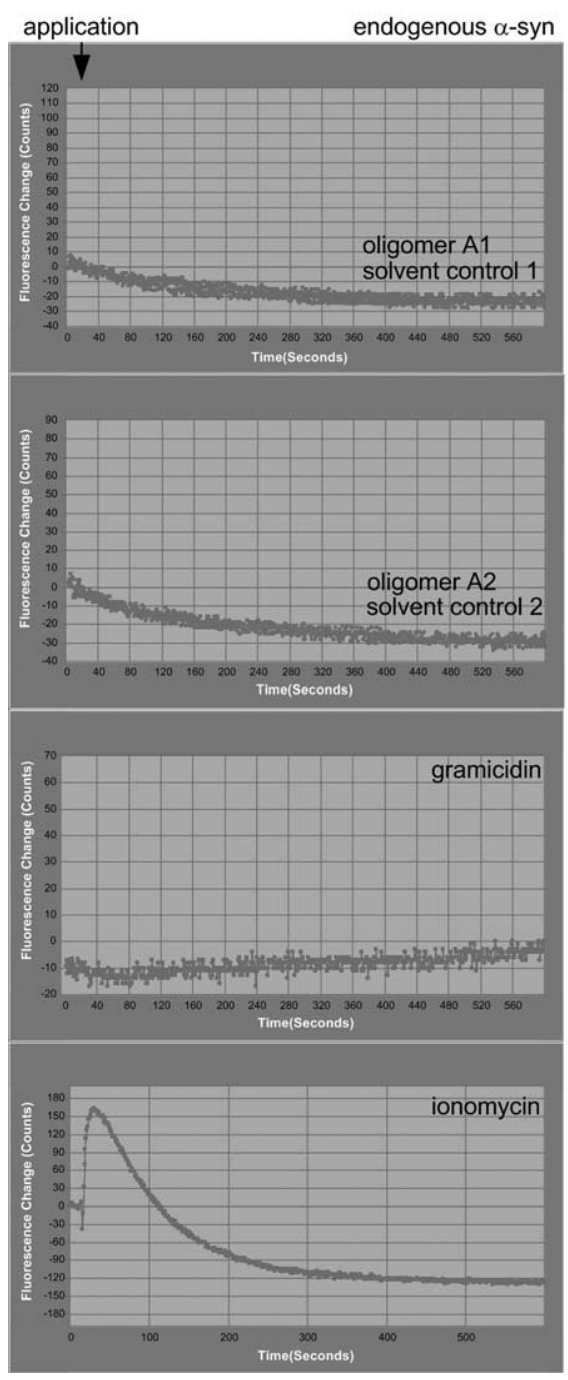

B

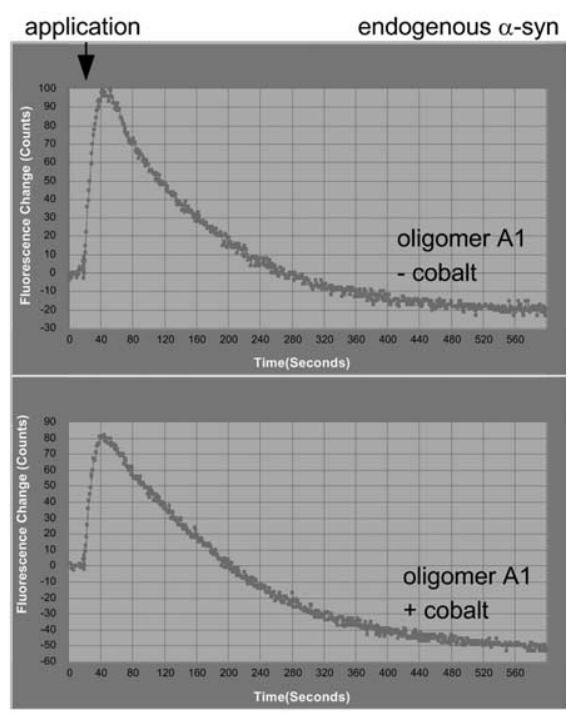

In contrast to type A oligomers, our other types of oligomers, types B and C, did not increase the level of intracellular calcium (data not shown). Moreover, we also did not detect a caspase activation or cell number reduction for oligomer types $\mathrm{B}$ and $\mathrm{C}$. Thus, type A oligomers were the only type of oligomers with annular structures and a calcium influx effect with a induction of cell death.

\section{Seeding characteristics of type B oligomers}

It has been shown previously that aggregation of $\alpha$-syn is a nucleation-dependent process in which preformed aggregates function as seeds (Wood et al., 1999). To analyze whether exogenously added oligomers have the propensity to seed cytosolic $\alpha$-syn, we treated SH-SY5Y cells stably overexpressing $\alpha$-syn mutant [A53T] and mock-transfected cells with endogenous levels of $\alpha$-syn with Alexa-488conjugated type B oligomers. Immunofluorescence staining showed colocalization of Alexa-488-conjugated type B oligomers (green) and the total amount of $\alpha$-syn (red) in overlaid images. We found yellowcolored aggregates within cells after oligomer type B treatment in both $\alpha$-syn mutant $[\mathrm{A} 53 \mathrm{~T}]$ and mock-transfected cells. Confocal images demonstrated that cells treated with Alexa-488-conjugated type B2 oligomers displayed a reduction in cytoplasmic $\alpha$-syn staining and an increase in yellow-colored intracellular aggregates (seeding), whereas solvent control-treated cells showed homogenous cytoplasmic staining of $\alpha$-syn (Fig. 9). Thus, exogenously added type B oligomers have entered the cell and seeded aggregation of cytosolic $\alpha$-syn with a resulting increased protein aggregation in one local area.

Notably, the oligomer types B1 and B2 did not cause an increase in intracellular calcium (data not shown). This supports the idea that the type B oligomers are different from the type A oligomers. Thus,

$\alpha$-Syn oligomer types $\mathrm{A} 1$ and $\mathrm{A} 2$ induced intracellular $\left[\mathrm{Ca}^{2+}\right]$ increase via influx of extracellular [C $\left.\mathrm{C}^{2+}\right]$ Kinetic plots illustrating typical signal responses to application of $0.1 \mu \mathrm{g} / \mu \mathrm{l} \alpha$-syn oligomer types A1 and A2 and positive controls, $1.5 \mu \mathrm{m}$ ionomycin, and $500 \mu \mathrm{g} / \mathrm{ml}$ gramicidin in $\left[\mathrm{Ca}^{2+}\right]$-free extracellular buffer. Each trace shows the mean fluorescence of 6000 mock-transfected SH-SY5Y cells expressing endogenous $\alpha$-syn. Intracellular $\left[\mathrm{Ca}^{2+}\right]$ signals evoked by oligomers type $A 1, A 2$, and gramicidin were completely abolished when cells were incubated in $\left[\mathrm{Ca}^{2+}\right]$-free extracellular buffer, whereas ionomycin-induced $\left[\mathrm{Ca}^{2+}\right]$ signals were persistent. $\boldsymbol{B},\left[\mathrm{Ca}^{2+}\right]$ signals evoked by oligomer types $\mathrm{A} 1$ and $\mathrm{A} 2$ are not reduced by cobalt, a nonspecific $\mathrm{Ca}^{2+}$ channel blocker. Each trace shows the typical mean fluorescence of 6000 mock-transfected SH-SY5Y cells after addition of type A1 oligomers in the presence and absence of cobalt. Type A oligomers showed a clear calcium channelindependent increase in intracellular $\left[\mathrm{Ca}^{2+}\right]$. This experiment was repeated two times and showed similar results.

be slightly higher in mutant $\alpha$-syn[A53T]-overexpressing cells than in cells with endogenous levels of $\alpha$-syn (Fig. 8A). Treatment with oligomer type Al caused, in both cell lines, a significant reduction in cell number, whereas mutant $\alpha$-syn [A53T]overexpressing cells seemed to be more affected in cell number reduction than mock-transfected cells. Although there was a lower caspase activation compared with the mock-transfected cells, there was a stronger cell number reduction in this cell line. This discrepancy might be explained by nonapoptotic cell death. We observed a strong and significant cell number reduction in mutant $\alpha$-syn[A53T]-overexpressing cells treated with type A2 oligomers. This is in accordance with the caspase- 3 results. Although the cell number reduction in mock-transfected cells treated with A2 oligomers is not statistically significant ( $p=$ $0.56)$ compared with solvent control 2, type A2 oligomers seem to reduce cell number also in mock-transfected cells (Fig. $8 \mathrm{~B}$ ). oligomer types B and A differ not only in their biophysical properties, but this difference also translates into different cellular effects.

\section{Seeding characteristics of type C oligomers}

Because type $\mathrm{C}$ oligomers also seemed to have different biophysical characteristics compared with oligomer types A and B, we assumed also different biological effects on cells. First, we investigated again the effect on calcium homeostasis in neuroblastoma cells. In none of our assays did type C oligomers cause an increase in intracellular calcium (data not shown).

We also investigated the seeding ability of type C oligomers as described for type B oligomers. Type C2 Alexa-488 oligomers induced as well a remarkable reduction in cytoplasmic staining of $\alpha$-syn and a tremendous seeding effect in both $\alpha$-syn mutant 

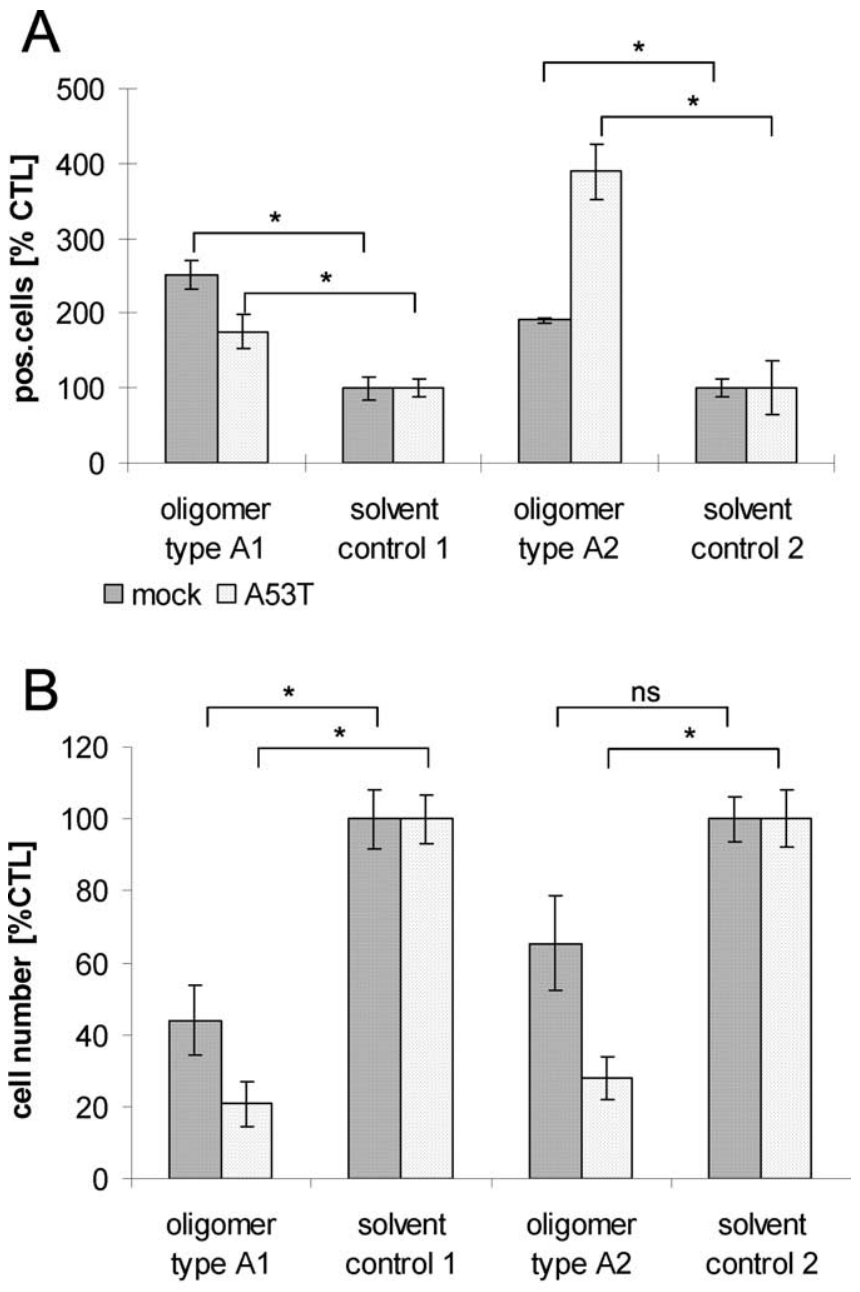

\section{$\square$ mock $\square$ A53T}

Figure 8. Toxicity of $\alpha$-syn oligomer types A1 and A2. A, Quantification of caspase-3 activation normalized to corresponding solvent controls; values are the mean \pm SEM; $n=3$. Treatment of mock-transfected SH-SY5Y cells or cells overexpressing $\alpha$-syn mutant A53T with 0.1 $\mathrm{mg} / \mathrm{ml}$ oligomer types A1 and A2 led to a significant activation of caspase-3 [unpaired $t$ test, ${ }^{*} p<0.05$ compared with data from corresponding solvent controls; oligomer type $A 1$ treated: mock, $\Delta=151$ (95\% Cl, 83.3-218.6); $\alpha$-syn[A53T], $\Delta=75.8$ (95\% (l, 5.8-145.9); oligomer type A2 treated: mock, $\Delta=90.9$ (95\% Cl, 54.6-127.2); $\alpha$-syn[A53T], $\Delta=288.9(95 \% \mathrm{Cl}$ 147.3-430.5)].B, Quantification of cell number reduction normalized to corresponding solvent controls. Values are shown as mean $\pm \mathrm{SEM} ; n=3$. Oligomer type A1 evoked, on both mocktransfected and stably overexpressing mutant $\alpha$-Syn[A53T] SH-SY5Y cell lines, a significant reduction in cell number. Oligomer type $\mathrm{A} 2$ led, on overexpressing mutant $\alpha$-syn[A53T] SHSY5Y cells, to a significant reduction in cell number [unpaired $t$ test, ${ }^{*} p<0.05$ compared with data from corresponding solvent controls; oligomer type A1 treated: mock, $\Delta=-56(95 \% \mathrm{Cl}$, -91.5 to -20.5$) ; \alpha$-syn [A53T], $\Delta=-79.3(95 \%(\mathrm{Cl},-104.9$ to -53.62$) ; 0$ oligomer type A2 treated: mock, $\Delta=-34.6(95 \% \mathrm{Cl},-75.6$ to -6.5$) ; \alpha$-syn[A53T], $\Delta=-72.1(95 \% \mathrm{Cl}$, -99.4 to -44.7$)$. Both oligomer types mediated their toxicity after $24 \mathrm{~h}$. ns, Not significant.

[A53T] and mock-transfected cells with endogenous levels of $\alpha$-syn (Fig. 10), whereas corresponding solvent control-treated cells showed a homogeneous $\alpha$-syn staining. Also, type C1 oligomers induced aggregate formation in both SH-SY5Y cell lines, whereas the seeding effect of type $\mathrm{C} 2$ oligomers was stronger. Also, in primary neurons, we were able to demonstrate a reduction in cytoplasmic $\alpha$-syn staining and a tremendous "yellow" aggregate formation near the nucleus after oligomer type C2 treatment. Corresponding solvent control-treated neurons showed a homogeneous cytoplasmic staining of $\alpha$-syn (Fig. 10C). Thus, also type $\mathrm{C}$ oligomers had the propensity to seed cytosolic $\alpha$-syn by accumulation of intracellular $\alpha$-syn within one local area after exogenous application in both SH-SY5Y cell lines and primary neurons.

Notably, type A oligomers had in none of our approaches any seeding propensity (data not shown).

All together, our data provide evidence that several different types of oligomers can be formed under various conditions, which differ in shape, morphology, and size. Consequently, these different types of oligomers have distinct biological effects on cells (summarized in Table 1).

\section{Discussion}

In this study we have shown that, depending on aggregation conditions, heterogeneous populations of $\alpha$-syn oligomers are forming, which can be differentiated based on their biophysical properties and cellular effects. Type A oligomers induced an increased membrane permeability and trigger cell death. Type B and C oligomers were able to enter cells directly and to seed intracellular $\alpha$-syn aggregation.

Many protocols of oligomer preparation have been described in the literature, but all were characterized with different methods, making it difficult to compare the different approaches. Here, we directly compared various types of oligomers by two single-particle analysis methods, AFM and FIDA, and cellular readouts. The influence of iron on in vitro aggregation of $\alpha$-syn has been reported by Uversky et al. (2001). These findings formed the basis for our present work.

Characterization of our type A oligomers with AFM revealed spherical oligomers from 2 to $6 \mathrm{~nm}$ in height. This is consistent with observations of other groups (Conway et al., 2000; Rochet et al., 2000; Volles et al., 2001; Hoyer et al., 2004; Apetri et al., 2006), although these studies were performed with far higher protein concentrations. Wood et al. (1999) had previously determined 28 $\mu \mathrm{M}$ as the critical concentration for $\alpha$-syn aggregation. Our approaches used four times less protein. This was possible because of the application of the highly sensitive FIDA analysis in contrast to the standard techniques used in the other studies. The method of oligomer generation used by Jensen et al. (2000) required protein concentrations 10-fold higher than our approaches and resulted mostly in fibrils after $7 \mathrm{~d}$ of incubations. In contrast, our samples still consisted mainly of oligomers and monomers at this time point, with no fibrils yet apparent. Prolonged incubation, however, lead to fibril formation (supplemental Fig. 5, available at www.jneurosci.org as supplemental material), suggesting that our oligomers were on pathway to fibrils.

Kayed and Glabe (2006) described the generation of homogeneous oligomer populations using a greatly differing protocol starting with seedless stock solutions. In contrast, our oligomer preparations turned out to be heterogeneous mixtures: FIDA data demonstrated that almost $50 \%$ of $\alpha$-syn contained in type A oligomers was in the monomeric form. An obvious explanation for the relatively high proportion of monomers in the type A preparations is an equilibrium between monomers and type A oligomers. After ultrafiltration to separate the monomer fraction and the oligomer type A fraction, monomers reappeared in the oligomer fraction (data not shown). The $\alpha$-syn monomers were, however, not seen by AFM, most probably because the monomers were washed off during the AFM sample preparation.

In addition to the generation and biophysical characterization of different oligomer types, we also investigated their biological effects after application to cells. We found that two types of our oligomers (B and C) entered into cells and seeded intracellular $\alpha$-syn aggregation. Our other type of oligomers (type A) did not 
A
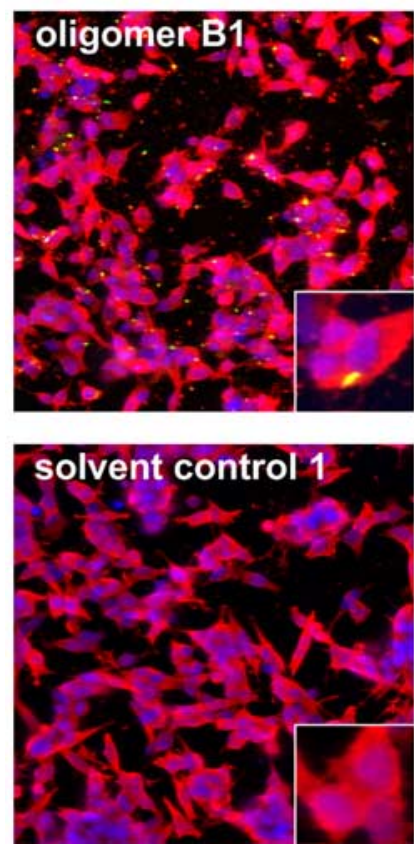
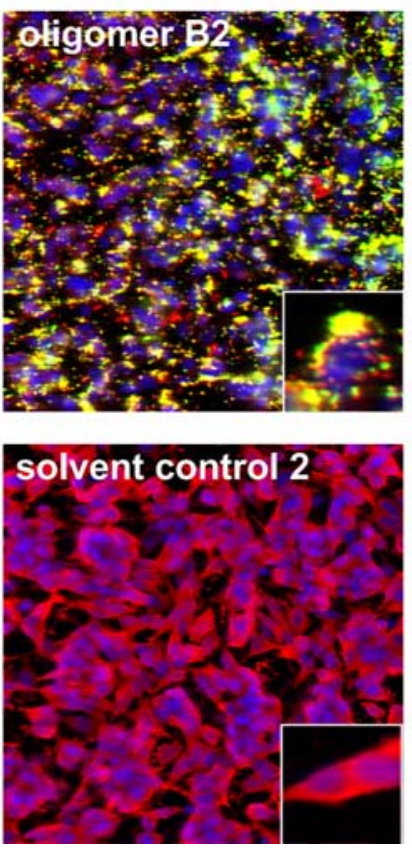

B
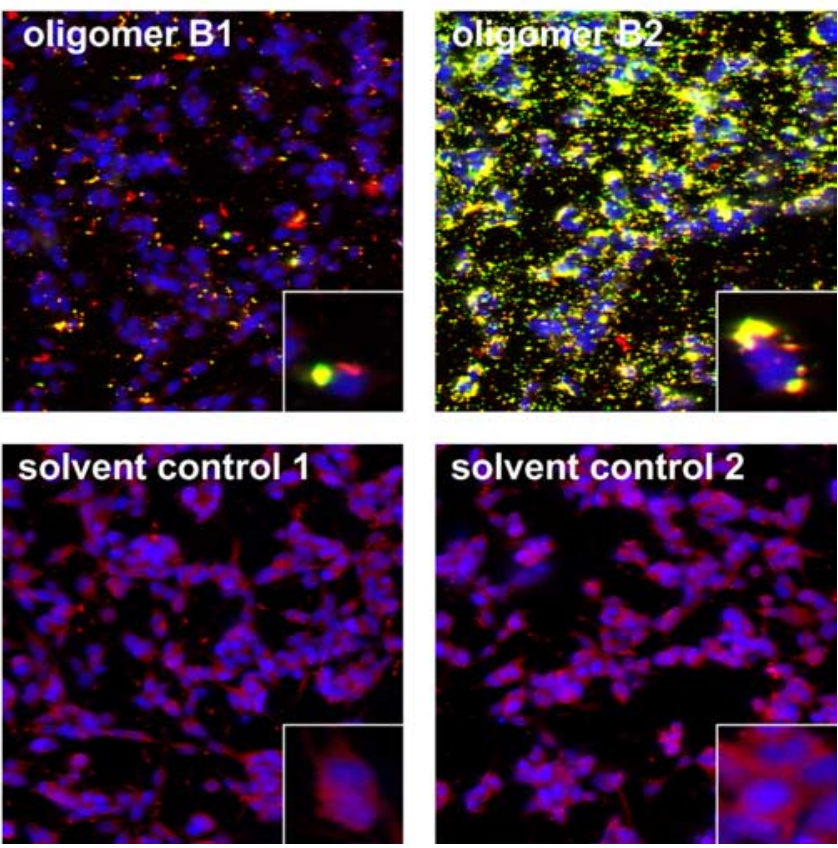

Figure 9. Seeding effect of $\alpha$-syn oligomer types B1 and B2. Immunocytochemical staining of $\alpha$-syn with ASY-1 antibody (in red) after treatment with $0.1 \mathrm{mg} / \mathrm{ml}$ Alexa-488-labeled oligomer types B1 and B2 (in green) or solvent controls is shown. $A, B$, Confocal images showed a reduction in cytoplasmic staining of $\alpha$-syn and an increase in cell-associated aggregates (seeding) in $S H$-SY5Y stably overexpressing $\alpha$-syn[A53T] ( $\boldsymbol{A}$ ) or mock-transfected SH-SY5Y with endogenous expression of $\alpha$-syn (B) when treated with oligomer type B2. Oligomer type B2 had a higher potential to seed aggregate formation than oligomer type B1. This experiment was repeated two times and showed similar results.

enter into cells. Instead, they seemed to act at the cellular membrane where they initiated an elevation of intracellular calcium. This increase in intracellular calcium occurred only in the presence of calcium in the extracellular buffer, suggesting that this effect is attributable to an influx from extracellular sources. We also shown that this calcium influx is independent of cobaltsensitive calcium channels. This is in contrast to the study by Adamczyk and Strosznajder (2006), who suggested that $\alpha$-syn induces a calcium influx via $\mathrm{N}$-type voltage-dependent $\mathrm{Ca}^{2+}$ channels. Their study differs greatly in two aspects. First, their model system is comprised of rat synaptoneurosomes, and second, they used monomeric $\alpha$-syn for their investigations. Therefore, the data of Adamczyk and Strosznajder (2006) are not directly comparable with our data.

Several mechanisms have been suggested to underlie the increase in intracellular calcium induced by amyloidogenic proteins: increase in membrane permeability (Demuro et al., 2005), insertion into the membrane and formation of a pore (Kawahara et al., 2000; Arispe, 2004; Lashuel and Lansbury, 2006), and a direct interaction with membrane components to destabilize the membrane structure (Muller et al., 1995; Mason et al., 1996; Avdulov et al., 1997; Green et al., 2004). Although we cannot exclude an increase in membrane permeability or mechanisms destabilizing the membrane structure, our data support the amyloid pore hypothesis suggested by Lashuel and Lansbury (2006). They demonstrated with synthetic vesicles a pore-forming mechanism of $\alpha$-syn protofibrils (Volles et al., 2001; Volles and Lansbury, 2002; Lashuel et al., 2002a). The influx of extracellular calcium observed in our experiments suggests that $\alpha$-syn pore formation occurs also in living cells. In addition, the calcium influx pattern of bacterial toxin gramicidin closely resembled the $\alpha$-syn oligomer type A-induced calcium influx. Thus, the pore forming mechanism mediated by oligomers type A could be sim- ilar to that of membrane-spanning pores formed by known protein toxins (e.g., hemolysin, latroxin, and aerolysin) (Valeva et al., 1997; Orlova et al., 2000; Wallace et al., 2000). Moreover, we also found a change in membrane potential in primary neurons after oligomer type A treatment. The observed depolarization could be the consequence of ion fluxes through pores in the membrane. Intriguingly, only type A oligomers contained annular structures. Recently, Tsigelny et al. (2007) showed, by using molecular modeling and molecular dynamics simulations, that $\alpha$-syn can form pentamers and hexamers forming a ring-like structure that can incorporate in the membrane. Direct evidence for the existence of amyloid pore-like structures in vivo has been provided by the extraction of annular $\alpha$-syn structures from postmortem brain tissues from a multiple-system atrophy patient (Pountney et al., 2005). Our annular type A oligomers, $45 \mathrm{~nm}$ in diameter, were similar to those extracted oligomers that ranged from 30 to $50 \mathrm{~nm}$ in diameter

These results suggest a disruption of cellular ion homeostasis followed by caspase activation and cell death via membrane spanning pores as one possible pathogenic mechanism of $\alpha$-syn oligomers that might also occur in vivo. A disruption of calcium homeostasis has been proposed for several related amyloidogenic oligomers, including amyloid $\beta$-peptide, prion, islet amyloid polypeptide, polyglutamine, and lysozyme (Demuro et al., 2005). Even prefibrillar aggregates of nondisease-related proteins have been shown to be internalized into cells followed by a rise of free calcium levels (Bucciantini et al., 2004). These findings strengthen the idea of a common mechanism of disruption of calcium homeostasis mediated by different prefibrillar aggregates of disease-related and nondisease-related proteins.

Our data demonstrate that oligomer type A-evoked increase in intracellular calcium was similar in cells overexpressing $\alpha$-syn [wt, A30P, A53T], and cells expressing only an endogenous 
A
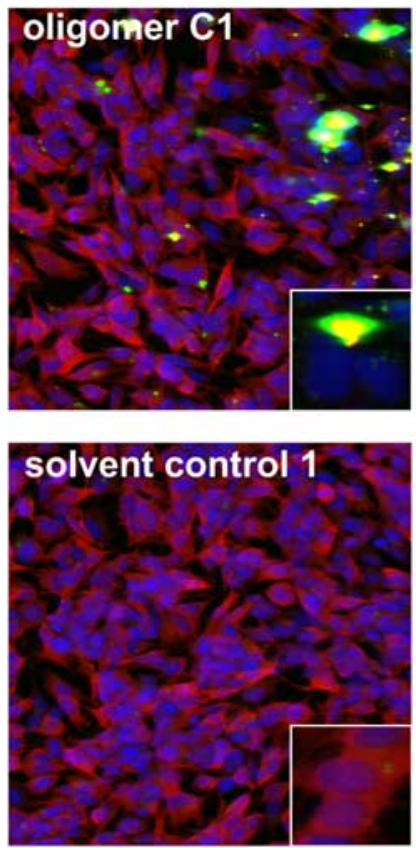
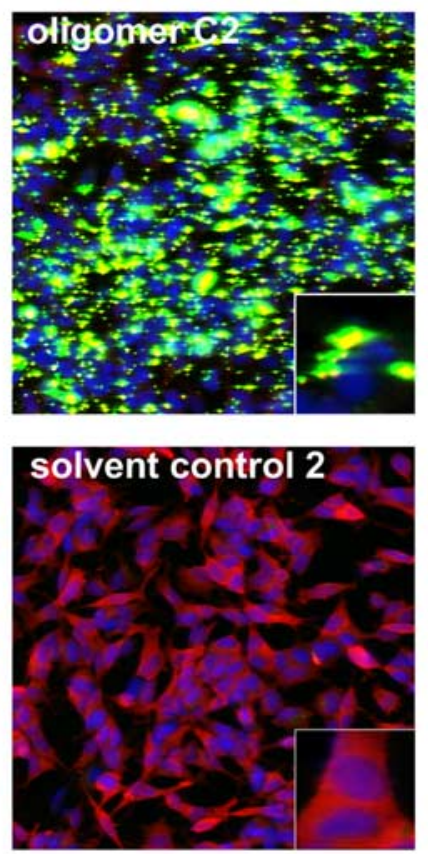

B
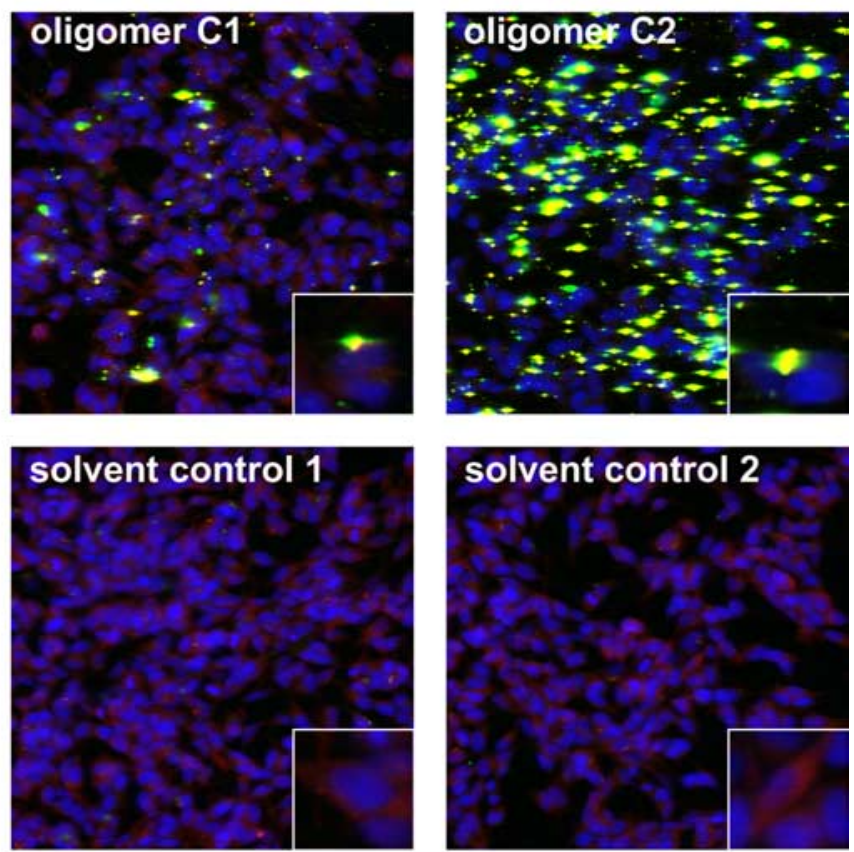

C

solvent control 2

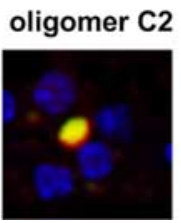

Figure 10. Seeding effect of $\alpha$-syn oligomer types C 1 and C2. Immunocytochemical staining of $\alpha$-syn with ASY-1 antibody (in red) after treatment with $0.1 \mathrm{mg} / \mathrm{ml}$ Alexa-488 labeled oligomers type $C 1$ and $C 2$ (in green) or solvent controls is shown. $A, B$, Confocal images showed a reduction in cytoplasmic staining of $\alpha$-syn and an increase in cell-associated aggregates (seeding) in SH-SY5Y stably overexpressing $\alpha$-syn mutant A53T $(\boldsymbol{A})$ or mock-transfected SH-SY5Y cells $(\boldsymbol{B})$ treated with oligomer type 2 . Oligomer type 2 had a higher potential to trigger aggregate formation than oligomer type C1. This experiment was repeated two times and showed similar results. C, Also, primary cortical neurons showed a decrease in cytoplasmic staining of $\alpha$-syn (red) and remarkable cell-associated $\alpha$-syn aggregate formation (yellow).

level of $\alpha$-syn. This suggests that intracellular $\alpha$-syn does not contribute under these experimental conditions to the pore formation, although other studies have shown that cells expressing mutant $\alpha$-syn[A53T] have a higher plasma membrane permeability (Furukawa et al., 2006).

In contrast, oligomer types $\mathrm{B}$ and $\mathrm{C}$ did not increase intracellular calcium (data not shown), but these oligomers could directly Table 1. Different types of $\alpha$-syn oligomers

\begin{tabular}{|c|c|c|c|c|c|c|}
\hline $\begin{array}{l}\text { Oligomer } \\
\text { type }\end{array}$ & $\begin{array}{l}\text { Annular } \\
\text { structures }\end{array}$ & $\begin{array}{l}\text { Particles }>5 \mathrm{~nm} \\
\text { in height }\end{array}$ & $\begin{array}{l}\text { Calcium } \\
\text { influx }\end{array}$ & $\begin{array}{l}\text { Cell } \\
\text { death }\end{array}$ & $\begin{array}{l}\text { Caspase } \\
\text { activation }\end{array}$ & Seeding \\
\hline A1 & + & - & + & + & + & - \\
\hline $\mathrm{A} 2$ & + & - & + & + & + & - \\
\hline B1 & - & + & - & - & - & + \\
\hline B2 & - & + & - & - & - & ++ \\
\hline C1 & - & + & - & - & - & + \\
\hline $\mathrm{C} 2$ & - & + & - & - & - & ++ \\
\hline
\end{tabular}

Overview of different types of $\alpha$-syn oligomers with their respective characteristics and biological effects. enter the cell and promote intracellular aggregate formation.

cate into cells, although the mechanism of aggregate internalization to date remains unclear (Bucciantini et al., 2004; Ahn et al., 2006). We were able to confirm that oligomer types $B$ and $C$ could also be internalized into cells and deploy then their seeding propportant role, also under pathophysiological conditions, because intriguing findings have shown previously that $\alpha$-syn aggregates could be secreted from cells and therefore possibly insult neighboring cells (Lee et al., 2005). However, because $\alpha$-syn is an intracellular protein, the in vivo situation can still differ from this model, because there could also be other mechanisms involved not considered in this study.

Previous studies have shown that monomeric $\alpha$-syn and prefibrillar aggregates from nondisease-related proteins can transloerties. A previous study has shown that membrane-bound $\alpha$-syn can seed intracellular $\alpha$-syn (Lee et al., 2002). The seeding effect observed in our study could be similar to the effect shown by Lee et al. (2002). Oligomer types B and C might resemble nucleating species as described also in cell-free studies (Hoyer et al., 2002). Seeding could also be one underlying mechanism for the ascending progression of $\alpha$-syn pathology within the brains of Parkinson's patients (Braak et al., 2003). 
In our experimental setup, oligomer types $\mathrm{B}$ and $\mathrm{C}$ did not induce caspase activation or cell loss (data not shown). This correlates with the lack of an increase in intracellular calcium. We hypothesize that, although oligomer types B and C seed intracellular aggregation of $\alpha$-syn, the resulting progression in aggregate formation in cell culture models is so fast because of the high levels of $\alpha$-syn overexpression that the nucleating species immediately end up as large aggregates, bypassing the toxic oligomeric intermediates. Therefore, it might well be that oligomers with seeding properties could still trigger toxic neurodegenerative processes in synucleinopathies, where $\alpha$-syn is present at physiological concentrations.

In conclusion, this study suggests that the aggregation process of $\alpha$-syn results in distinct populations of oligomeric forms with different cellular effects. The cellular effects of $\alpha$-syn oligomers described here in cell culture could resemble events that take place in PD patients. However, additional studies are needed to characterize the pathophysiologically relevant oligomeric forms in the brains of PD patients. Preventing the early events in oligomer formation might be a novel approach for the development of effective drugs for the treatment of PD and other synucleinopathies.

\section{References}

Adamczyk A, Strosznajder JB (2006) $\alpha$-Synuclein potentiates $\mathrm{Ca}^{2+}$ influx through voltage-dependent $\mathrm{Ca}^{2+}$ channels. NeuroReport 17:1883-1886.

Ahn KJ, Paik SR, Chung KC, Kim J (2006) Amino acid sequence motifs and mechanistic features of the membrane translocation of alpha-synuclein. J Neurochem 97:265-279.

Apetri MM, Maiti NC, Zagorski MG, Carey PR, Anderson VE (2006) Secondary structure of alpha-synuclein oligomers: characterization by raman and atomic force microscopy. J Mol Biol 355:63-71.

Arispe N (2004) Architecture of the Alzheimer's A $\beta$ P ion channel pore. J Membr Biol 197:33-48.

Auluck PK, Chan HY, Trojanowski JQ, Lee VM, Bonini NM (2002) Chaperone suppression of $\alpha$-synuclein toxicity in a Drosophila model for Parkinson's disease. Science 295:865-868.

Avdulov NA, Chochina SV, Igbavboa U, Warden CS, Vassiliev AV, Wood WG (1997) Lipid binding to amyloid $\beta$-peptide aggregates: preferential binding of cholesterol as compared with phosphatidylcholine and fatty acids. J Neurochem 69:1746-1752.

Bodner RA, Outeiro TF, Altmann S, Maxwell MM, Cho SH, Hyman BT, McLean PJ, Young AB, Housman DE, Kazantsev AG (2006) Pharmacological promotion of inclusion formation: a therapeutic approach for Huntington's and Parkinson's diseases. Proc Natl Acad Sci USA 103:4246-4251.

Braak H, Del TK, Rub U, de Vos RA, Jansen Steur EN, Braak E (2003) Staging of brain pathology related to sporadic Parkinson's disease. Neurobiol Aging 24:197-211.

Bucciantini M, Giannoni E, Chiti F, Baroni F, Formigli L, Zurdo J, Taddei N, Ramponi G, Dobson CM, Stefani M (2002) Inherent toxicity of aggregates implies a common mechanism for protein misfolding diseases. Nature 416:507-511.

Bucciantini M, Calloni G, Chiti F, Stefani M, Formigli L, Nosi D, Dobson CM (2004) Prefibrillar amyloid protein aggregates share common features of cytotoxicity. J Biol Chem 279:31374-31382.

Chartier-Harlin MC, Kachergus J, Roumier C, Mouroux V, Douay X, Lincoln S, Levecque C, Larvor L, Andrieux J, Hulihan M (2004) $\alpha$-Synuclein locus duplication as a cause of familial Parkinson's disease. Lancet 364:1167-1169.

Conway KA, Lee SJ, Rochet JC, Ding TT, Williamson RE, Lansbury Jr PT (2000) Acceleration of oligomerization, not fibrillization, is a shared property of both $\alpha$-synuclein mutations linked to early onset Parkinson's disease: implications for pathogenesis and therapy. Proc Natl Acad Sci USA 97:571-576.

Dauer W, Przedborski S (2003) Parkinson's disease: mechanisms and models. Neuron 39:889-909.

Demuro A, Parker I, Glabe CG, Mina E, Kayed R, Milton SC (2005) Calcium dysregulation and membrane disruption as a ubiquitous neurotoxic mechanism of soluble amyloid oligomers. J Biol Chem 280:17294-17300.

El-Agnaf OM, Salem SA, Paleologou KE, Curran MD, Gibson MJ, Court JA, Schlossmacher MG, Allsop D (2006) Detection of oligomeric forms of $\alpha$-synuclein protein in human plasma as a potential biomarker for Parkinson's disease. FASEB J 20:419-425.

Furukawa K, Matsuzaki-Kobayashi M, Hasegawa T, Kikuchi A, Sugeno N, Itoyama Y, Wang Y, Yao PJ, Bushlin I, Takeda A (2006) Plasma membrane ion permeability induced by mutant $\alpha$-synuclein contributes to the degeneration of neural cells. J Neurochem 97:1071-1077.

Goedert M (2001) $\alpha$-Synuclein and neurodegenerative diseases. Nat Rev Neurosci 2:492-501.

Goldberg MS, Lansbury Jr PT (2000) Is there a cause-and-effect relationship between $\alpha$-synuclein fibrillization and Parkinson's disease? Nat Cell Biol 2:E115-E119.

Gosavi N, Lee HJ, Lee JS, Patel S, Lee SJ (2002) Golgi fragmentation occurs in the cells with prefibrillar $\alpha$-synuclein aggregates and precedes the formation of fibrillar inclusion. J Biol Chem 277:48984-48992.

Green JD, Kreplak L, Goldsbury C, Li B, X, Stolz M, Cooper GS, Seelig A, Kistler J, Aebi U (2004) Atomic force microscopy reveals defects within mica supported lipid bilayers induced by the amyloidogenic human amylin peptide. J Mol Biol 342:877-887.

Haasen D, Wolff M, Valler MJ, Heilker R (2006) Comparison of G-protein coupled receptor desensitization-related $\beta$-arrestin redistribution using confocal and non-confocal imaging. Comb Chem High Throughput Screen 9:37-47.

Hoyer W, Antony T, Cherny D, Heim G, Jovin TM, Subramaniam V (2002) Dependence of $\alpha$-synuclein aggregate morphology on solution conditions. J Mol Biol 322:383-393.

Hoyer W, Cherny D, Subramaniam V, Jovin TM (2004) Rapid self-assembly of $\alpha$-synuclein observed by in situ atomic force microscopy. J Mol Biol 340:127-139.

Jensen PH, Islam K, Kenney J, Nielsen MS, Power J, Gai WP (2000) Microtubule-associated protein 1B is a component of cortical Lewy bodies and binds alpha-synuclein filaments. J Biol Chem 275:21500-21507.

Kask P, Palo K, Ullmann D, Gall K (1999) Fluorescence-intensity distribution analysis and its application in biomolecular detection technology. Proc Natl Acad Sci USA 96:13756-13761.

Kask P, Palo K, Fay N, Brand L, Mets U, Ullmann D, Jungmann J, Pschorr J, Gall K (2000) Two-dimensional fluorescence intensity distribution analysis: theory and applications. Biophys J 78:1703-1713.

Kawahara M, Kuroda Y, Arispe N, Rojas E (2000) Alzheimer's $\beta$-amyloid, human islet amylin, and prion protein fragment evoke intracellular free calcium elevations by a common mechanism in a hypothalamic $\mathrm{GnRH}$ neuronal cell line. J Biol Chem 275:14077-14083.

Kayed R, Glabe CG (2006) Conformation-dependent anti-amyloid oligomer antibodies. Methods Enzymol 413:326-344.

Kayed R, Head E, Thompson JL, McIntire TM, Milton SC, Cotman CW, Glabe CG (2003) Common structure of soluble amyloid oligomers implies common mechanism of pathogenesis. Science 300:486-489.

Kayed R, Edmonds B, Milton SC, Glabe CG, Sokolov Y, Hall JE, McIntire TM (2004) Permeabilization of lipid bilayers is a common conformationdependent activity of soluble amyloid oligomers in protein misfolding diseases. J Biol Chem 279:46363-46366.

Kruger R, Kuhn W, Muller T, Woitalla D, Graeber M, Kosel S, Przuntek H, Epplen JT, Schols L, Riess O (1998) Ala30Pro mutation in the gene encoding $\alpha$-synuclein in Parkinson's disease. Nat Genet 18:106-108.

Lashuel HA, Grillo-Bosch D (2005) In vitro preparation of prefibrillar intermediates of amyloid- $\beta$ and $\alpha$-synuclein. Methods Mol Biol 299:19-33.

Lashuel HA, Lansbury Jr PT (2006) Are amyloid diseases caused by protein aggregates that mimic bacterial pore-forming toxins? Q Rev Biophys 39:167-201.

Lashuel HA, Hartley D, Petre BM, Walz T, Lansbury Jr PT (2002a) Neurodegenerative disease: amyloid pores from pathogenic mutations. Nature 418:291.

Lashuel HA, Petre BM, Wall J, Simon M, Nowak RJ, Walz T, Lansbury Jr PT (2002b) $\alpha$-synuclein, especially the Parkinson's disease-associated mutants, forms pore-like annular and tubular protofibrils. J Mol Biol 322:1089-1102.

Lee HJ, Choi C, Lee SJ (2002) Membrane-bound $\alpha$-synuclein has a high aggregation propensity and the ability to seed the aggregation of the cytosolic form. J Biol Chem 277:671-678. 
Lee HJ, Patel S, Lee SJ (2005) Intravesicular localization and exocytosis of $\alpha$-synuclein and its aggregates. J Neurosci 25:6016-6024.

Levin J, Bertsch U, Kretzschmar H, Giese A (2005) Single particle analysis of manganese-induced prion protein aggregates. Biochem Biophys Res Commun 329:1200-1207.

Masliah E, Rockenstein E, Veinbergs I, Mallory M, Hashimoto M, Takeda A, Sagara Y, Sisk A, Mucke L (2000) Dopaminergic loss and inclusion body formation in $\alpha$-synuclein mice: implications for neurodegenerative disorders. Science 287:1265-1269.

Mason RP, Trumbore MW, Pettegrew JW (1996) Molecular membrane interactions of a phospholipid metabolite. Implications for Alzheimer's disease pathophysiology. Ann NY Acad Sci 777:368-373.

Mattson MP, Chan SL (2001) Dysregulation of cellular calcium homeostasis in Alzheimer's disease: bad genes and bad habits. J Mol Neurosci 17:205-224.

Muller WE, Koch S, Eckert A, Hartmann H, Scheuer K (1995) $\beta$-Amyloid peptide decreases membrane fluidity. Brain Res 674:133-136.

Nuscher B, Kamp F, Mehnert T, Odoy S, Haass C, Kahle PJ, Beyer K (2004) Alpha-synuclein has a high affinity for packing defects in a bilayer membrane: a thermodynamics study. J Biol Chem 279:21966-21975.

Orlova EV, Rahman MA, Gowen B, Volynski KE, Ashton AC, Manser C, van HM, Ushkaryov YA (2000) Structure of alpha-latrotoxin oligomers reveals that divalent cation-dependent tetramers form membrane pores. Nat Struct Biol 7:48-53.

Park JY, Lansbury Jr PT (2003) Beta-synuclein inhibits formation of alphasynuclein protofibrils: a possible therapeutic strategy against Parkinson's disease. Biochemistry 42:3696-3700.

Polymeropoulos MH, Lavedan C, Leroy E, Ide SE, Dehejia A, Dutra A, Pike B, Root H, Rubenstein J, Boyer R, Stenroos ES, Chandrasekharappa S, Athanassiadou A, Papapetropoulos T, Johnson WG, Lazzarini AM, Duvoisin RC, Di IG, Golbe LI, Nussbaum RL (1997) Mutation in the alphasynuclein gene identified in families with Parkinson's disease. Science 276:2045-2047.

Pountney DL, Voelcker NH, Gai WP (2005) Annular $\alpha$-synuclein oligomers are potentially toxic agents in $\alpha$-synucleinopathy. Hypothesis. Neurotox Res 7:59-67.

Rochet JC, Conway KA, Lansbury Jr PT (2000) Inhibition of fibrillization and accumulation of prefibrillar oligomers in mixtures of human and mouse $\alpha$-synuclein. Biochemistry 39:10619-10626.

Singleton AB, Farrer M, Johnson J, Singleton A, Hague S, Kachergus J, Hulihan M, Peuralinna T, Dutra A, Nussbaum R, Lincoln S, Crawley A, Han- son M, Maraganore D, Adler C, Cookson MR, Muenter M, Baptista M, Miller D, Blancato J, et al. (2003) $\alpha$-Synuclein locus triplication causes Parkinson's disease. Science 302:841.

Tsigelny IF, Bar-On P, Sharikov Y, Crews L, Hashimoto M, Miller MA, Keller SH, Platoshyn O, Yuan JX, Masliah E (2007) Dynamics of $\alpha$-synuclein aggregation and inhibition of pore-like oligomer development by $\beta$-synuclein. FEBS J 274:1862-1877.

Uversky VN, Li J, Fink AL (2001) Metal-triggered structural transformations, aggregation, and fibrillation of human alpha-synuclein. A possible molecular NK between Parkinson's disease and heavy metal exposure. J Biol Chem 276:44284-44296.

Valeva A, Palmer M, Bhakdi S (1997) Staphylococcal alpha-toxin: formation of the heptameric pore is partially cooperative and proceeds through multiple intermediate stages. Biochemistry 36:13298-13304.

Volles MJ, Lansbury Jr PT (2002) Vesicle permeabilization by protofibrillar alpha-synuclein is sensitive to Parkinson's disease-linked mutations and occurs by a pore-like mechanism. Biochemistry 41:4595-4602.

Volles MJ, Lee SJ, Rochet JC, Shtilerman MD, Ding TT, Kessler JC, Lansbury Jr PT (2001) Vesicle permeabilization by protofibrillar $\alpha$-synuclein: implications for the pathogenesis and treatment of Parkinson's disease. Biochemistry 40:7812-7819.

Wallace AJ, Stillman TJ, Atkins A, Jamieson SJ, Bullough PA, Green J, Artymiuk PJ (2000) E. coli hemolysin E (HlyE, ClyA, SheA): x-ray crystal structure of the toxin and observation of membrane pores by electron microscopy. Cell 100:265-276.

Wolff M, Haasen D, Merk S, Kroner M, Maier U, Bordel S, Wiedenmann J, Nienhaus GU, Valler M, Heilker R (2006) Automated high content screening for phosphoinositide 3 kinase inhibition using an AKT 1 redistribution assay. Comb Chem High Throughput Screen 9:339-350.

Wood SJ, Wypych J, Steavenson S, Louis JC, Citron M, Biere AL (1999) $\alpha$-Synuclein fibrillogenesis is nucleation-dependent. Implications for the pathogenesis of Parkinson's disease. J Biol Chem 274:19509-19512.

Zarranz JJ, Alegre J, Gomez-Esteban JC, Lezcano E, Ros R, Ampuero I, Vidal L, Hoenicka J, Rodriguez O, Atares B, Llorens V, Gomez TE, del Ser T, Munoz DG, de Yebenes JG (2004) The new mutation, E46K, of alphasynuclein causes Parkinson and Lewy body dementia. Ann Neurol 55:164-173.

Zemanova L, Schenk A, Hunt N, Nienhaus GU, Heilker R (2004) Endothelin receptor in virus-like particles: ligand binding observed by fluorescence fluctuation spectroscopy. Biochemistry 43:9021-9028. 